\title{
Basement-involved reactivation in foreland fold-and-thrust belts: the Alpine-Carpathian Junction (Austria)
}

\author{
P. GRANADO*†, W. THÖNY $\ddagger$ N. CARRERA*, O. GRATZER $\ddagger$ P. STRAUSS \\ \& J. A. MUÑOZ* \\ * Institut de Recerca Geomodels, Departament de Geodinàmica i Geofísica, Facultat de Geologia, Universitat de \\ Barcelona, Martí i Franquès s/n, 08028 Barcelona, Spain \\ $\ddagger$ OMV AUSTRIA Exploration and Production GmbH, Trabrennstraße 6-8. 1020 Vienna, Austria
}

(Received 21 October 2015; accepted 7 January 2016; first published online 23 February 2016)

\begin{abstract}
The late Eocene - early Miocene Alpine-Carpathian fold-and-thrust belt (FTB) lies in the transition between the Eastern Alps and the Western Carpathians, SE of the Bohemian crystalline massif. Our study shows the involvement of crystalline basement from the former European Jurassic continental margin in two distinct events. A first extensional event coeval with Eggerian-Karpatian (c. 28-16 Ma) thin-skinned thrusting reactivated the rift basement fault array and resulted from the large degree of lower plate bending promoted by high lateral gradients of lithospheric strength and slab pull forces. Slab break-off during the final stages of collision around Karpatian times (c. 17$16 \mathrm{Ma}$ ) promoted large-wavelength uplift and an excessive topographic load. This load was reduced by broadening the orogenic wedge through the reactivation of the lower-plate deep detachment beneath and ahead of the thin-skinned thrust front (with the accompanying positive inversion of the basement fault array) and ultimately, by the collapse of the hinterland summits, enhanced by transtensional faulting. Although this work specifically deals with the involvement of the basement in the AlpineCarpathian Junction, the main conclusions are of general interest to the understanding of orogenic systems.
\end{abstract}

Keywords: Alpine-Carpathian Junction, thin-skinned, thick-skinned, basin inversion, slab break-off.

\section{Introduction}

There is a growing body of literature recognizing that the commonly used transition from thick-skinned dominated regions in the orogenic hinterlands to purely thinskinned dominated regions in adjacent forelands does not reflect the heterogeneous degree of crustal coupling observed in fold-and-thrust belts (FTB) worldwide (e.g. Cooper, 2007; Goofey et al. 2010). Compelling evidence for mixed modes of deformation taking place at different places and times for one single FTB have been undoubtedly recognized (e.g. Salas et al. 2001; Lacombe \& Mouthereau, 2002; Mouthereau et al. 2002; Lacombe, Mouthereau \& Angelier, 2003; Butler \& Mazzoli, 2006; Butler, Tavarnelli \& Grasso, 2006). The fundamental factors controlling the degree of crustal coupling within FTB are: (1) the presence and distribution of efficient decollement levels (e.g. Davis \& Engelder, 1985; Macedo \& Marshak, 1999; Carola et al. 2013; Farzipour-Saein, Nilfouroushan \& Koyi, 2013; Muñoz et al. 2013); (2) the inheritance of rift-related structures and amount of convergence (e.g. Desegaulx, Kooi \& Cloetingh, 1991; Macedo \& Marshak, 1999; Marshak, 2004; Butler, Tavarnelli \& Grasso, 2006; Brown et al. 2012); (3) the orientation and magnitude of the stress field as well as the strain rate (e.g. Rebaï, Philip \& Taboada, 1992; Ziegler, Clo-

$\nmid$ Author for correspondence: pablomartinez_granado@ub.edu etingh \& van Wees, 1995; Vernant et al. 2004; Zoback, 2010); and (4) the integrated lithospheric strength profile as well as its evolution through time (e.g. Burov \& Diament, 1995; Ziegler, Cloetingh \& van Wees, 1995; Cloetingh \& Burov, 1996; Ziegler, van Wees \& Cloetingh, 1998; Ziegler et al. 2001; Watts \& Burov, 2003; Holdsworth, 2004; Butler, Tavarnelli \& Grasso, 2006; Mouthereau, Watts \& Burov, 2013).

In addition to this, widespread extension is a recognized process taking place during orogenic shortening as a result of several mechanisms such as unroofing of the orogenic wedge and lateral escape of crustal blocks (e.g. Molnar \& Tapponnier, 1975; Platt, 1986; Dewey, 1988; Ratschbacher et al. 1991; Fossen, 2000). Extension and creation of accommodation space in the lower plate of orogenic wedges (i.e. in the foreland basin) has also been recognized in relation to the flexural isostatic subsidence in response to the growing weight of the orogenic wedge and the slab pull and slab retreat forces derived from the sinking lower plate (e.g. Bradley \& Kidd, 1991; DeCelles \& Gilles, 1996; Andeweg \& Cloetingh, 1998; García-Castellanos \& Cloetingh, 2012; Schlunegger \& Kissling, 2015). Such complex evolution of orogenic systems and associated FTB has also been demonstrated by numerical (e.g. GarcíaCastellanos, Fernàndez \& Torné, 1997; Andeweg \& Cloetingh, 1998; Beaumont et al. 2000; Jammes \& Huismans, 2012; Ruh, Kaus \& Burg, 2012; Nilfouroushan et al. 2013; Erdös et al. 2014) and analogue 


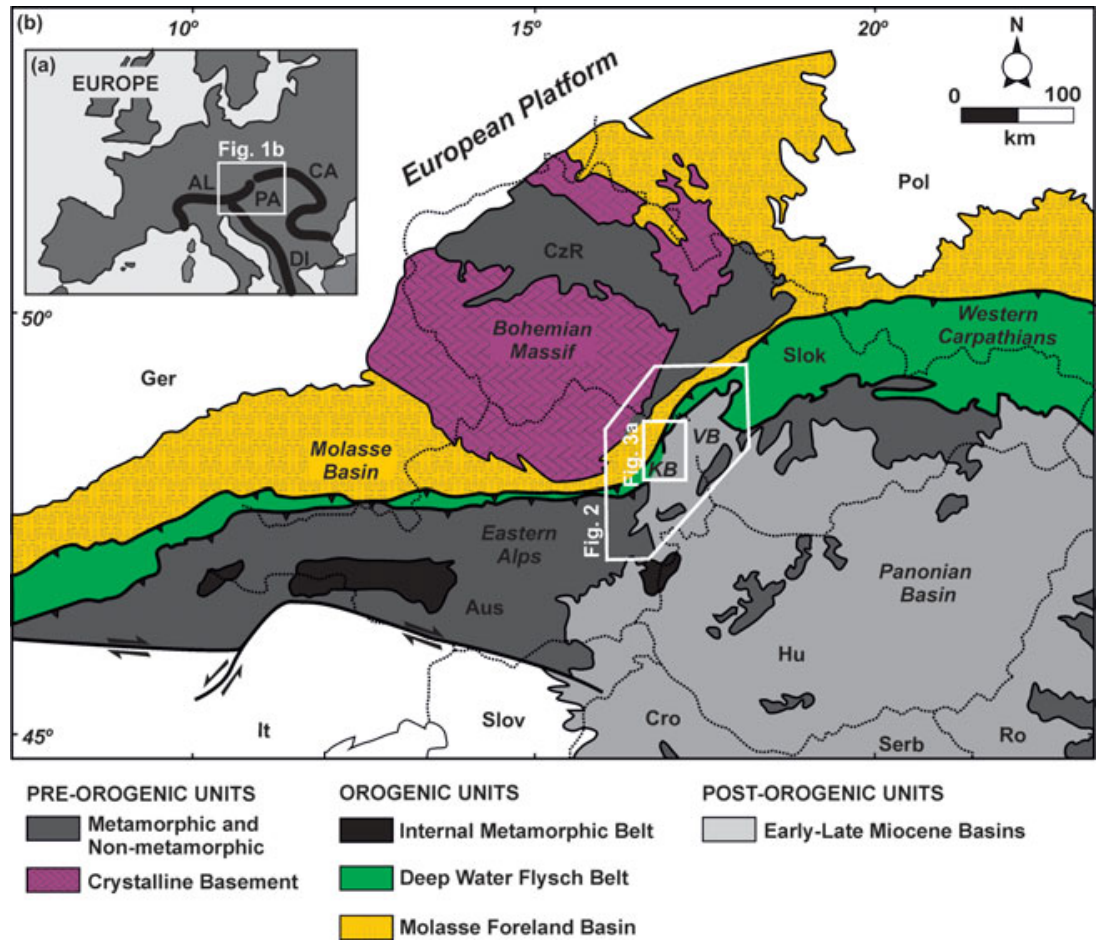

Figure 1. (Colour online) (a) Geological setting of the studied area. AL - Alps; CA - Carpathians; PA - Pannonian Basin; DI Dinarides. (b) The Alpine-Carpathian Junction is located in the transition from the Eastern Alps to the Western Carpathians within the boundaries of Austria, Slovakia and the Czech Republic. Inset shows the location of Figures 2 and 3a. Aus - Austria; Cro - Croatia; CzR - Czech Republic; Ger - Germany; Hu - Hungary; Pol - Poland; Ro - Romania; Slok - Slovakia; Slov - Slovenia; Serb - Serbia; VB - Vienna Basin; KB - Korneuburg Basin. Modified from Tari (2005).

modelling studies (e.g. Mugnier et al. 1997; Nilfouroushan \& Koyi, 2007; Malavieille, 2010; Graveleau, Malavieille \& Dominguez, 2012; Perrin et al. 2013).

In this work, we provide evidence for the involvement of crystalline basement by basement fault reactivation (in extension and shortening modes) beneath and ahead of the external parts of Alpine-Carpathian thin-skinned FTB. Evidence arises from the interpretation of seismic datasets, cross-section construction and calculated fault-displacement profiles. These were integrated with existing gravity data (Geofyzika, unpub. report, 1999; Lenhardt et al. 2007), recent and historic earthquake distributions (Reinecker \& Lenhardt, 1999; Lenhardt et al. 2007), lithospheric rheology (Andeweg \& Cloetingh, 1998; Lankreijer et al. 1999) and thermochronological studies (Mazzoli et al. 2010; Andreucci et al. 2013, 2015; Castelluccio et al. 2015).

\section{Geological setting}

The Alpine-Carpathian FTB is located in the transition between the Eastern Alps and the Western Carpathians, between the Vienna Basin to the SE and the Bohemian massif to the NW (Fig. 1). A simplified geological evolution of the studied area is summarized in a tectono-chronostratigraphic chart (Fig. 2), whereas the main structural elements and regional structure are illustrated in Figure 3. The reader should refer to Figure 2 for the correlation of the Mediterranean and
Central Paratethys Miocene stages. The basement of the Alpine-Carpathian FTB presents a general tilting towards the south (Wessely, 1987, 1988) which relates to the subduction of the European lower plate and the associated orogenic flexure of the foreland region (Turcotte \& Schubert, 1982). The basement is elongated towards the south in the so-called Bohemian Spur extending as much as $50 \mathrm{~km}$ beneath the FTB, as confirmed by seismic data (Grassl et al. 2004; this study), gravity data (Geofyzika, unpub. report, 1999; Fig. 4) and the many hydrocarbon exploration wells reaching the crystalline substrate (Wessely, 2006). The Bohemian spur is delineated and dissected by NESW- and NW-SE-striking basement faults and, to a minor extent, by N-S- and $\mathrm{E}-\mathrm{W}$-oriented fault systems (Wessely, 1987; Wagner, 1996, 1998). Gravity data (Geofyzika, unpub. report, 1999) confirms the regional structural trends derived from these previous studies as well as the location and distribution of the major basin depocentres (Fig. 4). The oldest rocks unconformably overlying the crystalline basement are represented by Carboniferous-Permian units related to the latest Variscan cycle (Kroner et al. 2008). The Lower Austria Mesozoic Basin (hereafter referred to as the LAMB) locates to the east of the Bohemian Spur. The LAMB was formed during the JurassicCretaceous development of the Alpine Tethys (Wessely, 1987; Zimmer \& Wessely, 1996; Wagner, 1998; Ziegler et al. 2001; Schmid et al. 2004; Handy et al. 2010; Handy, Ustaszewski \& Kissling, 2015). The basin 


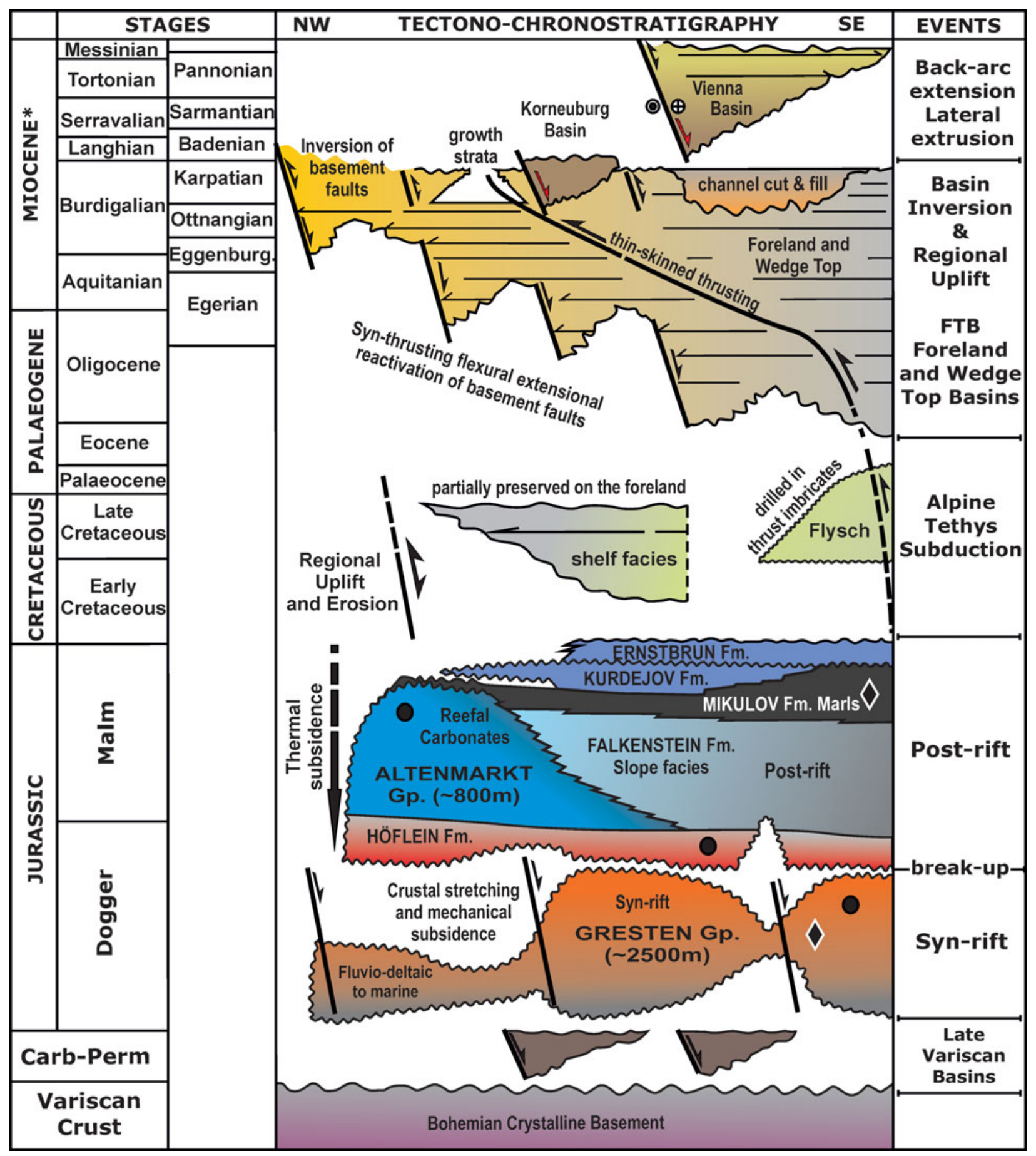

Figure 2. (Colour online) Simplified tectono-chronostratigraphic chart of the Alpine-Carpathian Junction. Central Paratethys stages (as defined by Piller, Harzhauser \& Mandic, 2007) and corresponding Mediterranean equivalents are included for reference.

defines a large concave-to-the-SE segment belonging to the European Jurassic continental margin (Fig. 3). The LAMB sedimentary infill consists of pre-rift, synrift and post-rift megasequences (Fig. 2). The Middle Jurassic pre-rift to syn-rift megasequence consists of a continental to fluvio-deltaic transgressive sequence represented by the Gresten Group. This unit hosts both reservoir and source-rock intervals (Sachsenhofer et al. 2006). The post-rift megasequence is represented by the onset of a carbonate platform to slope system which commences with the Middle Jurassic Höflein
Formation (e.g. Sauer, Seifert \& Wessely, 1992). The Höflein Formation is made up of silicified cherty and sandy dolostones and constitutes the most important reservoir in the Alpine-Carpathian sub-thrust region (e.g. Sauer, Seifert \& Wessely, 1992; Zimmer \& Wessely, 1996; Sachsenhofer et al. 2006). The remaining part of the post-rift megasequence is constituted by Upper Jurassic reef build-ups and slope to deeperwater facies as represented by the Mikulov, Ernsbrunn and Kurdejov formations. The Mikulov marls represent the most important source rock of the Alpine- 

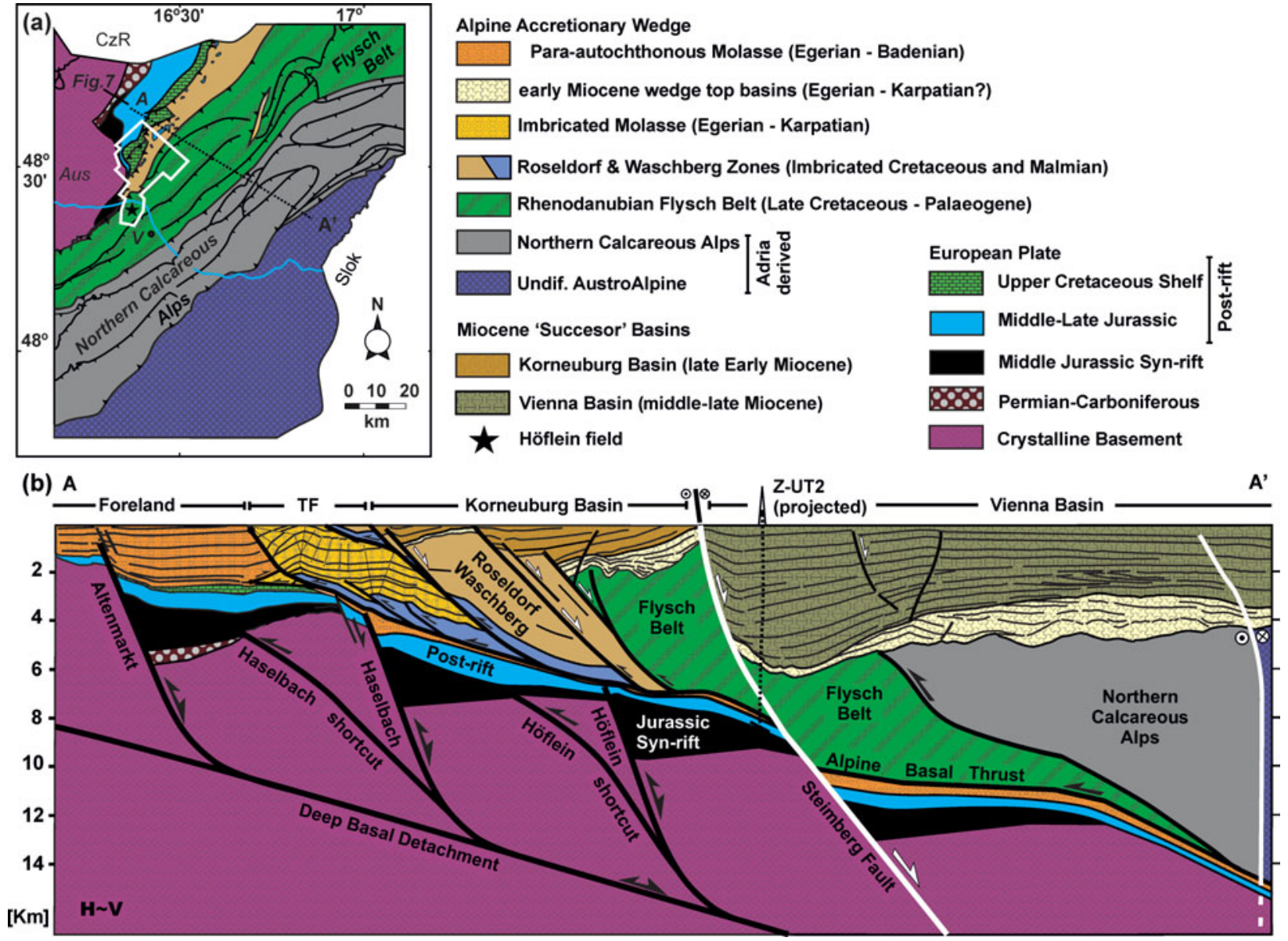

Figure 3. (Colour online) (a) Neogene subcrop map of the Alpine-Carpathian Junction in Lower Austria with the location of the 3D seismic data. (b) Regional cross-section where the Para-autochthonous foreland and lower plate, the Alpine-Carpathian FTB and the overlying Miocene 'successor' basins are illustrated. Modified from Zimmer \& Wessely (1996), Wessely (2006), Roeder (2010) and Beidinger \& Decker (2014). Aus - Austria; Slok - Slovakia; CzR - Czech Republic; TF - thrust front.

Carpathian Junction (Sauer, Seifert \& Wessely, 1992). The remaining part of the post-rift is constituted by an unevenly distributed Late Cretaceous shelf unconformably overlying the Jurassic units (Wessely, 1987, 2006).

The Alpine-Carpathian FTB developed from the late Eocene - early Miocene N- to NW-directed shortening and overthrusting of the Alpine Tethys continental margin successions on the previously rifted European Platform (e.g. Fodor, 1995; Decker \& Peresson, 1996; Frisch et al. 1998; Ziegler et al. 2001; Schmid et al. 2004; Ustaszewski et al. 2008; Handy et al. 2010; Beidinger \& Decker, 2014; Handy, Ustaszewski \& Kissling, 2015). This thin-skinned shortening was preceded by an earlier phase of shortening in Cretaceous times responsible for thick-skinned deformation and uplift on the Alpine Foreland (e.g. Nachtmann \& Wagner, 1987; Schröder, 1987). This early thick-skinned deformation is probably responsible for the partial erosion and uneven distribution of the Cretaceous cover as reported by Wessely (1987). From SE to NW, the AlpineCarpathian thin-skinned orogenic wedge is represented by the Austroalpine (including the Northern Calcareous Alps), the Rhenodanubian Flysch, the Waschberg, Roseldorf and Imbricated Molasse zones and the Para- autochthonous Molasse (Fig. 3). Thin-skinned thrusting followed a general forwards breaking sequence characterized by strong transpressional and transtensional deformation (e.g. Wessely, 1987; Decker, Meschede \& Ring, 1993; Fodor, 1995; Linzer, Ratschbacher \& Frisch, 1995; Decker \& Peresson, 1996; Linzer et al. 1997, 2002; Peresson \& Decker, 1997; Hölzel et al. 2010; Beidinger \& Decker, 2014). The characteristic structural styles are represented by imbricate thrust systems and related folds detached along the Alpine basal thrust which soles within the Mikulov Formation and the Para-autochthonous Molasse foreland sediments. Notoriously, the foreland basin is narrowest in front of the Bohemian Spur (c. $9 \mathrm{~km})$, widening out up to 10 times to the west and to the east (Fig. 1). Large incisions and canyons in the Alpine-Carpathian foreland (e.g. Dellmour \& Harzhauser, 2012) provide evidence for a regional long-wavelength uplift in latest early Miocene time (i.e. Karpatian), such as that reported for the Upper Austria Molasse (Andeweg \& Cloetingh, 1998). More recently, thermochronological studies to the ENE of the studied area in the Central Western Carpathians (e.g. Danišik et al. 2010; Anczkiewicz, Środoń \& Zattin, 2013; Andreucci et al. 2013; Castelluccio et al. 2015) also support large Miocene exhumation events related 

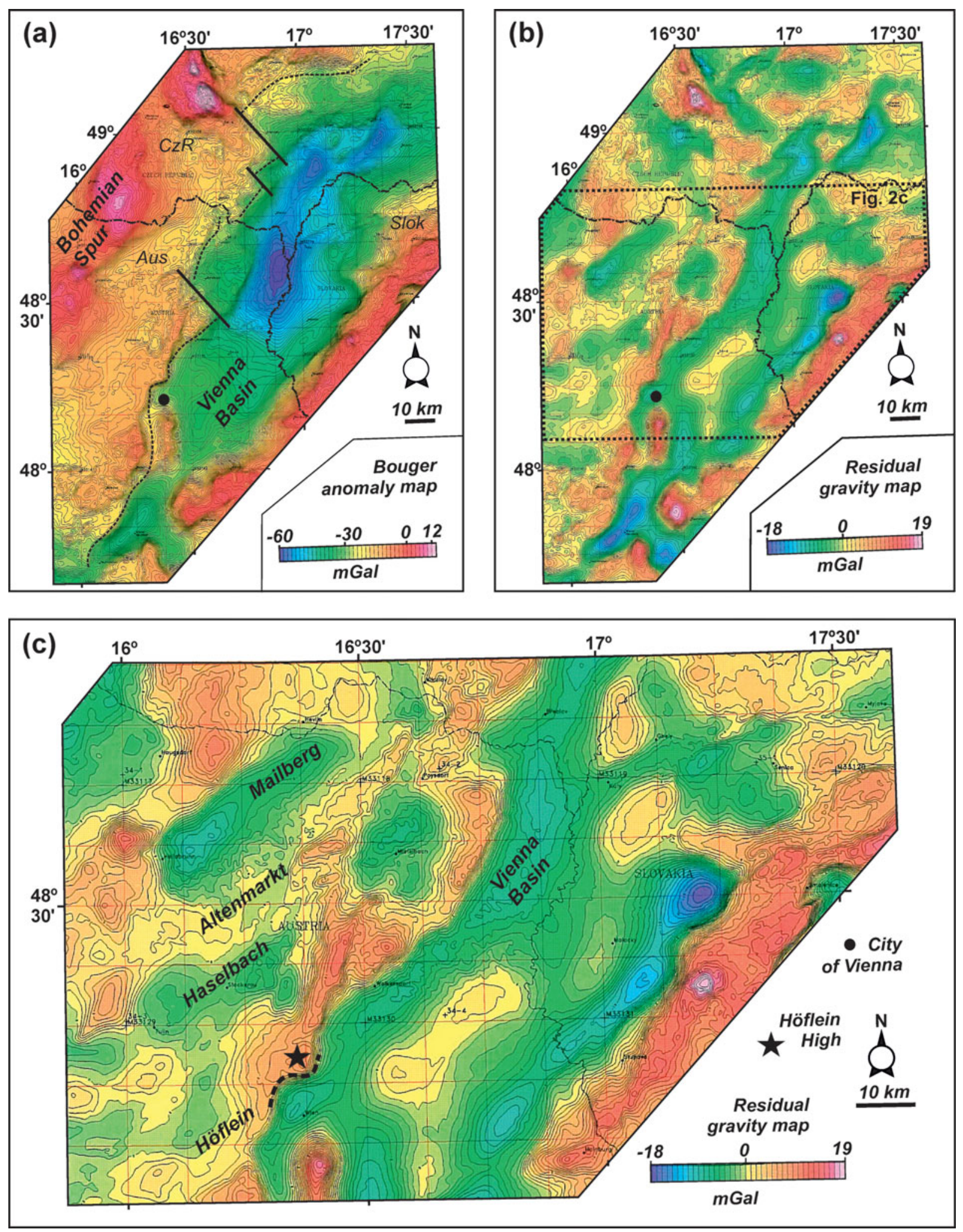

Figure 4. (Colour online) Gravity maps of the Alpine-Carpathian Junction of Austria, Slovakia and Czech Republic. (a) The Bouger anomaly map shows the trend of the Bohemian crystalline massif (higher gravity readings) and the NE-SW-striking Vienna Basin (low gravity readings). (b) The residual gravity map illustrates several NE-SW gravity lows associated with the structural trends of the half-graben basins in the foreland and sub-thrust region as well as the Vienna Basin. (c) Inset of residual gravity map in (b), illustrating the gravity lows associated with the Mailberg, Altenmarkt, Haselbach and Höflein half-grabens in more detail. The E-W-striking Höflein high is shown as a prominent high related to the significant change in the basement structural trend. Data from Geofyzika (unpub. report, 1999) and provided by OMV Exploration and Production GmbH. 
to thrusting, erosion and post-thrusting extension (e.g. Mazzoli et al. 2010; Zattin et al. 2011).

On top of the Flysch Zone and the more internal parts of the Alpine-Carpathian FTB, the latest early Miocene - late Miocene 'successor' basins (i.e. Korneuburg, Vienna and subsidiary basins; Figs 2, 3) were developed. These basins are characterized by up to $6000 \mathrm{~m}$ thick Miocene depocentres associated with strike-slip pullapart basins and related fault systems (e.g. Royden, 1985; Wessely, 1987, 1988; Fodor, 1995; Strauss et al. 2001, 2006; Hinsch, Decker \& Peresson, 2005; Arzmüller et al. 2006; Hölzel et al. 2010). The origin of these basins has been traditionally ascribed to the lateral extrusion of the Alpine edifice encompassing the extensional collapse of an orogenically thickened and gravitationally unstable crust, as well as the tectonic escape driven by the retreat of the eastern Carpathian subduction zone (e.g. Ratschbacher et al. 1991; Decker \& Peresson, 1996; Linzer, 1996; Frisch et al. 1998; Wölfler et al. 2011). In this sense, the Steinberg and Mur-Mürz fault systems of the Vienna Basin most probably played a significant role on the Alpine lateral extrusion and the late dismantling of the orogenic edifice. It has also been suggested that the lateral extrusion and the end of the eastern Carpathian subduction is responsible for the late Miocene - Pliocene gentle inversion of some of these 'successor' basins (e.g. Ratschbacher et al. 1991; Decker \& Peresson, 1996; Sachsenhofer et al. 2000; Strauss et al. 2001; Genser, Cloetingh \& Neubauer, 2007).

In addition, a significant amount of work has been dedicated to constraining the Cenozoic kinematics in the Eastern Alps (e.g. Thöny et al. 2006), the Alpine-Carpathian Junction and the Western Carpathians through palaeomagnetic studies (e.g. Márton et al. 2003, 2013). Their research concluded that significant Miocene anticlockwise vertical axis rotations took place, and that the present shape of the AlpineCarpathian arc is partly due to a certain amount of oroclinal bending. However, more recent works (e.g. Szaniawski et al. 2013) report an inconsistency in their results compared to those from previous works. These authors indicate palaeomagnetic declinations similar to those expected for stable parts of the European Platform, implying limited amounts of vertical axis rotations in the Western Carpathians. This debate shows the geological complexity of the studied area and deserves further consideration; however, it is considered to be outwith the scope of this manuscript.

\section{Dataset and methodologies}

For our study we have mostly used three-dimensional (3D) and 2D seismic data. The $3 \mathrm{D}$ volume is a poststack depth-migrated merge covering $c .550 \mathrm{~km}^{2}$ with a maximum recorded depth of $7 \mathrm{~km}$. Spacing of the NE$\mathrm{SW}$-trending Inlines is $15 \mathrm{~m}$, whereas for the NW-SEtrending cross-lines it is $30 \mathrm{~m}$. The quality of the $3 \mathrm{D}$ seismic data is generally good but decreases in structurally complicated areas. In addition, seismic velocity inversions associated with the post-rift carbonate units also produce local reduced resolution. The studied area is also covered by a dense network of $2 \mathrm{D}$ time-migrated seismic profiles which cover the foreland deformation front without 3D coverage. Several tens of wells containing a downhole suite of gamma ray, sonic, resistivity, spontaneous potential surveys, checkshot logs and biostratigraphically constrained formation tops were tied to the seismic data. Gravity anomaly maps were used to illuminate the shape of the Bohemian crystalline basement, the border of the LAMB as well as the extent and strike of the Jurassic half-graben basins, and the overlying 'successor' Miocene basins. All data were integrated to identify and constrain the regional structure with an emphasis on the LAMB and its basement fault array. Key megasequence boundaries were defined based on well intersections, the regional unconformities observed, their internal architecture and seismic reflectors' geometries, their seismic facies and the relationships of all these features to the major structures of the basin.

\section{Seismic interpretation and structural analysis}

Regional well-tied surfaces for the top of the crystalline basement and the base of the post-rift megasequence were generated from the 3D data volume (Fig. 5). The basement fault array of the LAMB is relatively well imaged in the seismic data from the foreland in the NW to the hinterland in the SE. In the studied area, the LAMB is constituted by a series of basement-involved faults that from NW to SE are referred to here as: Mailberg, Altenmarkt, Haselbach, Höflein, Kronberg and Kasernberg faults (Fig. 5). The Mailberg fault is imaged by a series of NW-SE-striking 2D time-migrated profiles in the foreland region, whereas the remaining basement faults are imaged by the 3D depth-migrated seismic cube. Fault surfaces were generated for these faults and their average orientations extracted from the 3D model (Fig. 5c, d).

\section{4.a. The LAMB basement fault array}

The LAMB basement fault array is constituted by steeply to moderately SE-dipping extensional faults, whereas minor antithetic faults are steeply to moderately NW-dipping (Fig. 5). These basement-involved faults are arranged in segments with slightly different orientations, striking from NNE-SSW to E-W and NW-SE, but overall configuring a general NE-SW trend (Fig. 5c). Major faults display lengths in excess of $10 \mathrm{~km}$ along-strike. In the studied area, the general trend of the basement fault array is roughly parallel to the strike of the overlying thin-skinned thrust front (Fig. 3). One NW-SE-striking basement fault (i.e. trending approximately perpendicular to the general basement fault array) was interpreted from the $3 \mathrm{D}$ seismic data (Fig. 5). According to the Bouguer anomaly map, this fault set could correspond to transfer systems segmenting the regional basement fault trend 

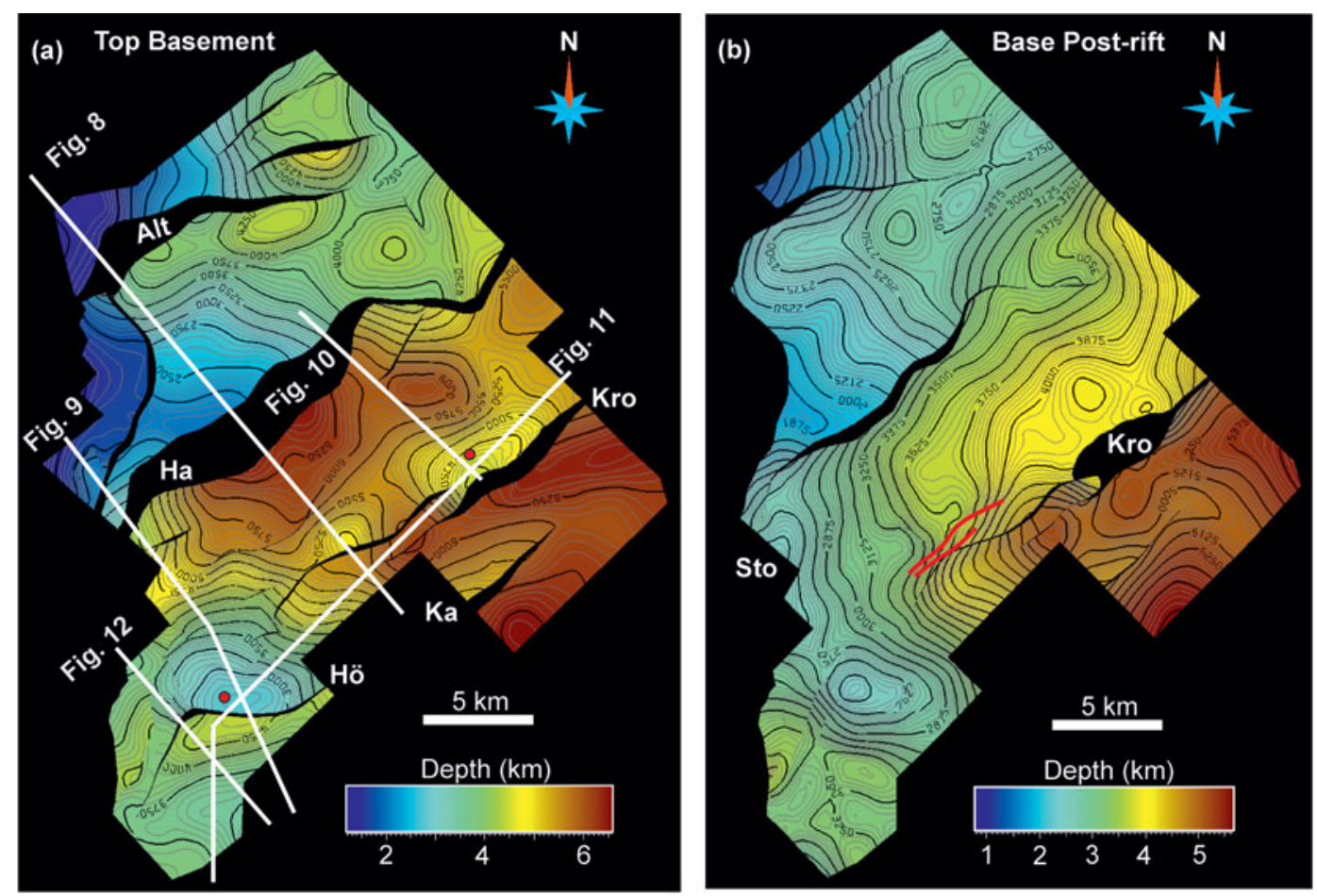

(c)

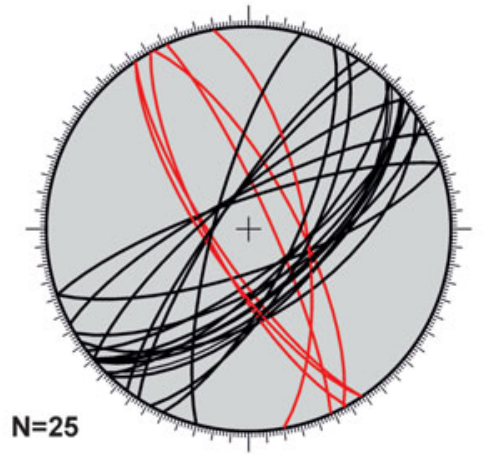

(d)
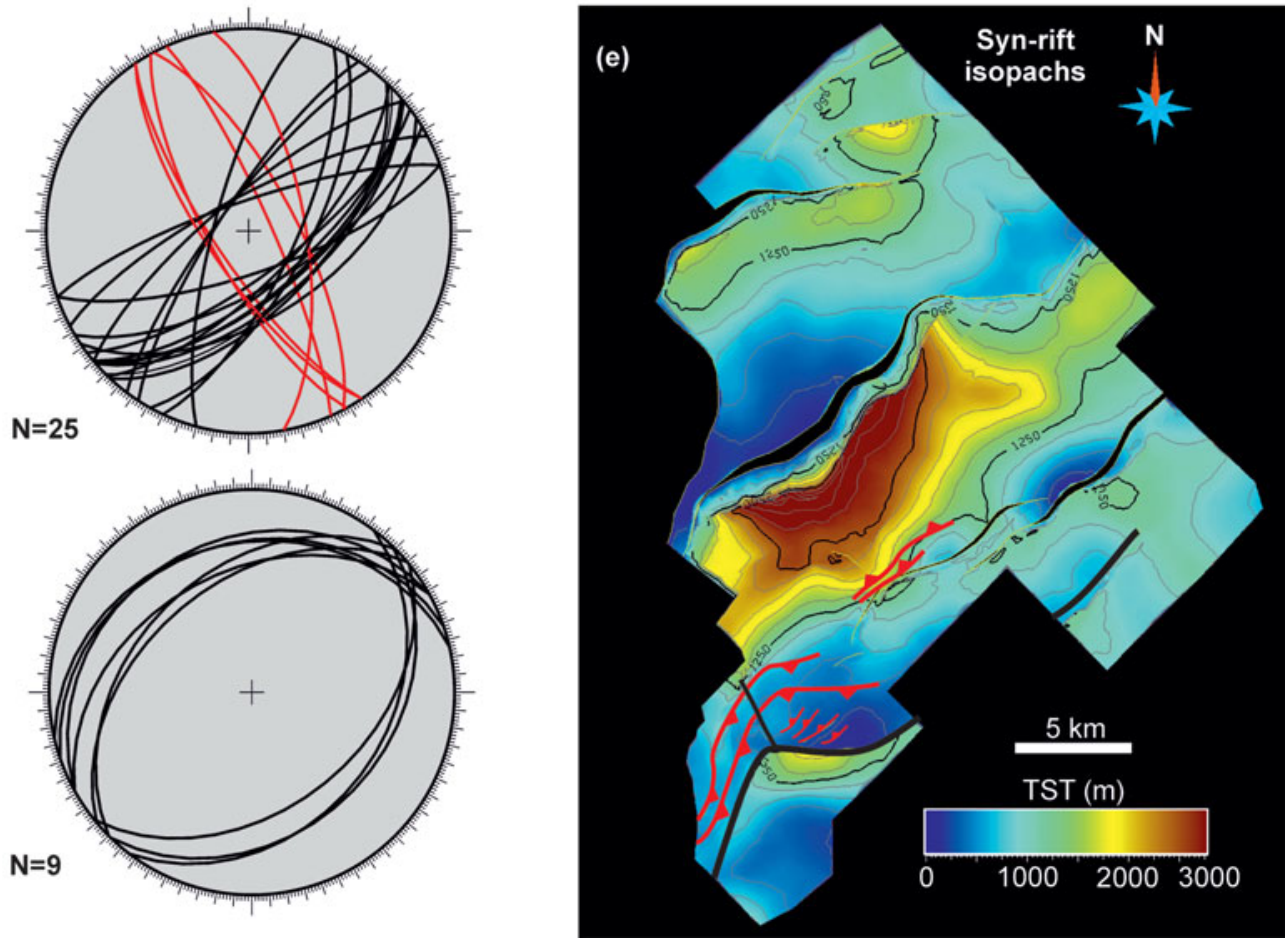

Figure 5. (Colour online) Depth structure maps. (a) Top of crystalline basement. (b) Base of the post-rift megasequence (i.e. Höflein Formation). (c) Stereographic projection showing the orientation of the interpreted fault systems, with great circles representing faults. Note the predominant NE-SW-striking steeply dipping sets (in black) corresponding to the large Jurassic rift faults. The NW-SEstriking set (in red) corresponds to the less-abundant release and transfer faults. (d) Stereographic projection showing the predominant NE-SW strike of the inversion-related fault system. All stereographic plots are equal-area, lower-hemisphere projections. (e) Syn-rift isopach map (i.e. true stratigraphic thickness). The largest syn-rift depocentre is related to the Haselbach fault, whereas the thickest syn-rift in the Höflein half-graben is related to its E-W-striking segment. Alt - Altenmarkt fault; Ha - Haselbach fault; Hö - Höflein fault; Kro - Kronberg fault; Ka - Kasernberg fault; Sto - Stockerau anticline. Red dots in (a) indicate the position of the Höflein and Kronberg basement highs. Stereoplots generated with OpenPlot software (Tavani et al. 2011). 
(Fig. 4a). Other NW-SE-striking faults in the order of tens to hundreds of metres long (i.e. up to two orders of magnitude smaller than the major faults) are localized within the basement and pre-rift to early syn-rift infill. Characteristically, these small faults display lower throw values than the master faults and are here interpreted as release faults (sensu Destro, 1995). This type of fault accommodates the along-strike stretching of the hanging-wall layers during regional extension and accounts for the NW-SE-striking fault sets shown in the fault strike diagram (Fig. 5c).

As no fault plane reflections are shown by the seismic data, the shape of the basement faults has been resolved from the location of the reflector's cut-offs and by the geometry of the corresponding hangingwall layers (e.g. White, Jackson \& McKenzie, 1986; Xiao \& Suppe, 1992; Withjack \& Schlische, 2006). The hanging-wall layers of the major basement-involved faults display either a straight panel dipping into the fault or slightly kinked panels indicating that the underlying extensional faults display a planar to slightly kinked geometry. The average spacing of the basementinvolved faults is $c .10 \mathrm{~km}$ measured normal to the strike of the structures. According to this, the general structure of the LAMB corresponds to a series of tilted fault blocks and associated half-graben basins that belong to the former Alpine Tethys Jurassic continental margin. The basal detachment of these faults should be located at around $12 \mathrm{~km}$ depth, close to the base of the seismogenic crust (Sibson, 1983; Twiss \& Moores, 1992).

\section{4.b. Assessment of basement fault reactivation}

The evolution of the LAMB basement fault array was studied by documenting the observed structural styles and the relative timing of cross-cutting relationships. In addition, a quantitative approach was taken by computing fault-displacement profiles (i.e. fault length $\mathrm{v}$. throw values). Fault displacement profiles were calculated for the top basement and the base of the post-rift megasequence given their fundamental role in constraining the magnitude of fault reactivation (e.g. Williams, Powell \& Cooper, 1989; Turner \& Williams, 2004). This is based on the assumption that during the post-rift, subsidence is mostly controlled by the thermal re-equilibration of the lithosphere as opposed to the syn-rift subsidence which is fundamentally fault controlled (e.g. McKenzie, 1978; Allen \& Allen, 2005). Large offsets affecting the post-rift megasequence are therefore indicative of post-rift fault reactivation. Faultdisplacement profiles illustrate the along-strike variation of throw but can also indicate which faults (or fault segments) underwent extensional reactivation and inversion (e.g. Thomas \& Coward, 1995; Willemse, Pollard \& Aydin, 1996). The obtained throw values for each fault should be taken as representative values of the minimum vertical offset, as additional faults and folds of sub-seismic entity might have contributed to the total offset.
The observed displacement along the basementinvolved faults of the LAMB decreases upwards by developing fault-propagation folds or forced folds (e.g. Stearns, 1978; Withjack, Olson \& Peterson, 1990; Cornfield \& Sharp, 2000; Cosgrove \& Ameen, 2000; Maurin and Niviere, 2000; Khalil \& McClay, 2002; Jackson, Gawthorpe \& Sharp, 2006; Tavani \& Granado, 2015). These folds also affect the post-rift megasequence, the foreland sediments of the Molasse Basin and, locally, the overlying thin-skinned thrust system. For the major faults, the top of the crystalline basement displays fault-parallel hanging-wall synclines (Fig. 5a) which trend parallel to slightly oblique to the orientation of the immediate fault segment. The Altenmarkt fault displays two of these synclines separated by a fault perpendicular ridge (Fig. 5a). Calculated fault displacement profiles (Fig. 6) indicate displacement maxima slightly shifted sideways from the central position of the faults. These observations suggest that the extensional faults grew to a certain point by the lateral linkage of isolated fault segments (Peacock \& Sanderson, 1991; Cartwright, Mansfield \& Trudgill, 1996; Willemse, Pollard \& Aydin, 1996).

Syn-rift sediment distribution was calculated and represented as a True Stratigraphic Thickness map (Fig. 5e). The calculated map indicates several syn-rift depocentres juxtaposed to the major basement faults as well as stratigraphic thickness lows associated with the uplifted footwalls of the basement faults. The largest syn-rift depocentre is associated with the Haselbach fault, where the syn-rift reaches up to $2770 \mathrm{~m}$ in thickness. Broadly speaking, the LAMB is characterized by a well-preserved extensional architecture, mostly inherited from the Jurassic rifting episode. In the following, evidence for the reactivation of the basement fault array following the sedimentation of the synrift megasequence from cross-sections, generated surfaces and fault displacement profiles, is provided. In the cross-sections, geometrical characteristics typical of extensional faulting but also typical of positive inversion of the extensional fault array are shown.

\section{4.b.1. The Mailberg fault}

The Mailberg fault is located in the foreland region ahead of the thin-skinned thrust front. This fault runs along-strike for as much as $30 \mathrm{~km}$. It is only covered by 2D time-migrated profiles, but its associated hangingwall depocentre is well shown as a NE-SW-striking gravity low (Fig. b, c). In the central segment of the Mailberg fault, the top of the crystalline basement is folded into an open hanging-wall syncline. The top of the basement has been downthrown in excess of $2 \mathrm{~s}$ two-way time, although thickness difference of the Jurassic syn-rift sequence between the footwall and the hanging wall is less than $1 \mathrm{~s}$ (Figs 6a, 7). Well and seismic data show that the post-rift megasequence in the hanging wall displays net extensional displacements along most of the length of the fault. In addition, well data indicate that to the SW the post-rift is not present 
Mailberg Fault

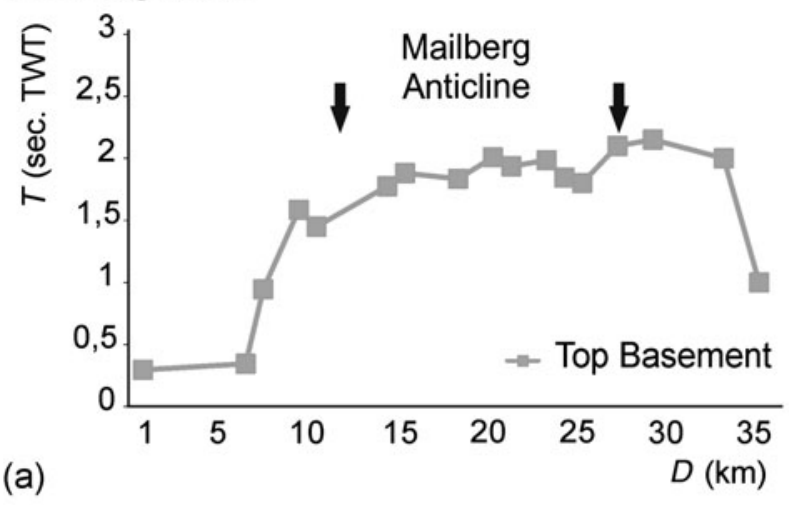

\section{Haselbach Fault}

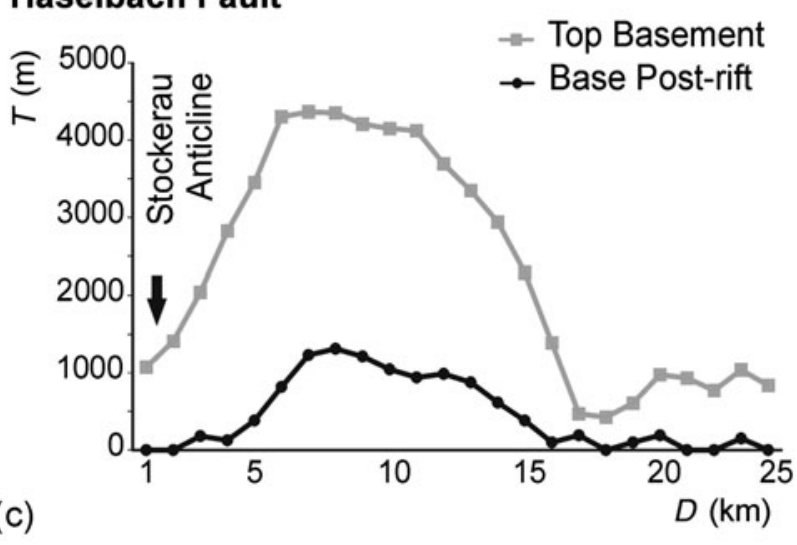

\section{Altenmarkt Fault}

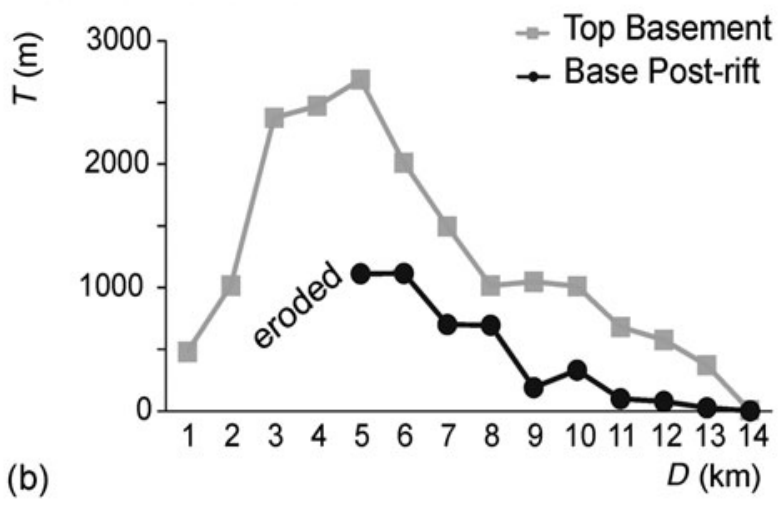

\section{Kronberg Fault}
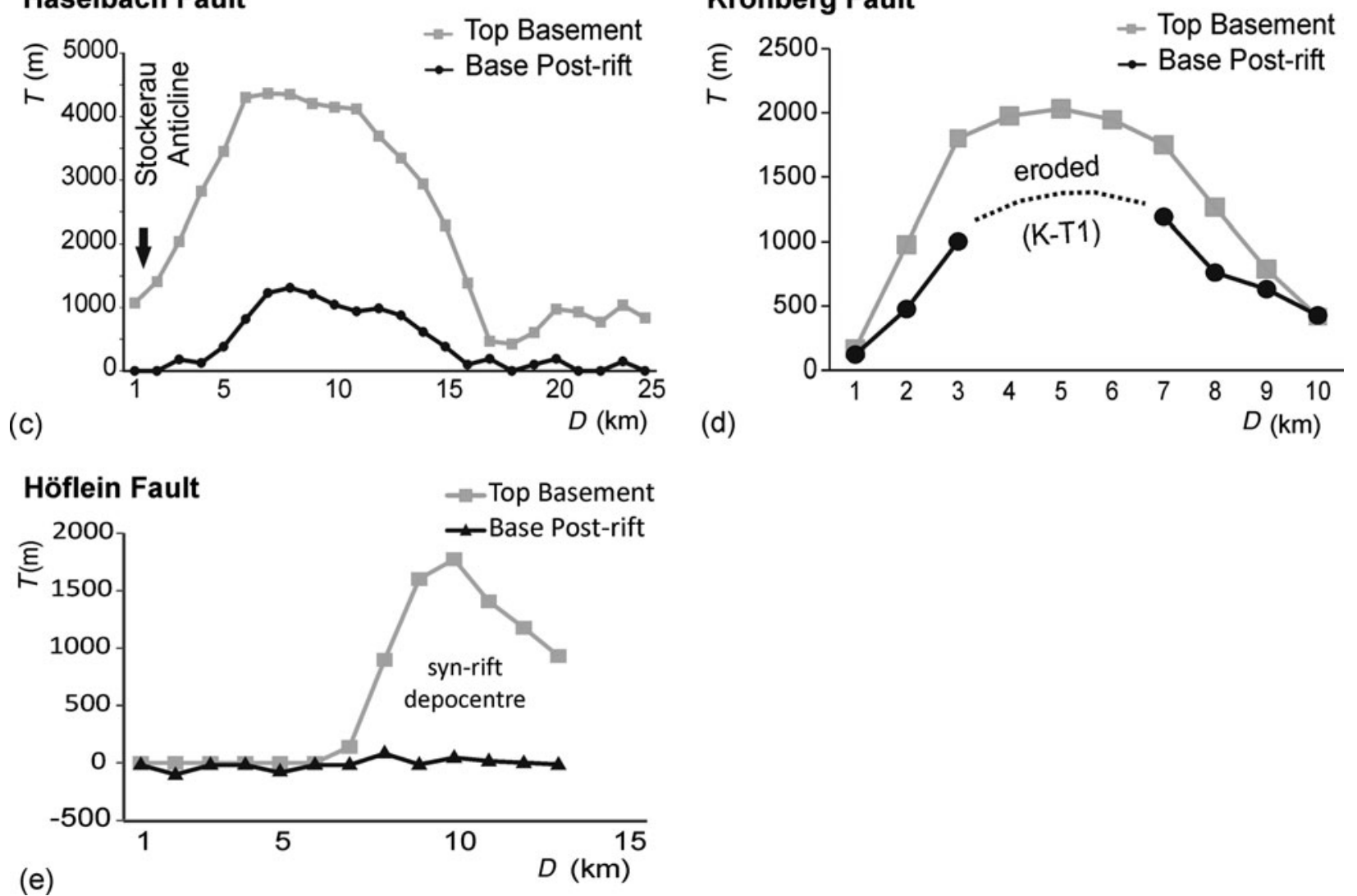

Figure 6. Fault displacement profiles for the studied basement faults. $D$ is the length of the extensional fault measured along-strike and $T$ (throw) is vertical offset. Note all throw values are in metres, except for the Mailberg fault which is reported as two-way time. Note the extensional offset in excess of $1000 \mathrm{~m}$ for the base of the post-rift, providing evidence for the early Miocene extensional reactivation event. The observed erosion of the basal post-rift section (see (b) and (d) plots) is also spatially coincident with the location of maximum throw values. The Höflein fault displays either no extensional offset for the post-rift section or minor reverse offset, indicating the partial positive inversion of the fault.

in the footwall; it has therefore been eroded or nondeposited. On the other hand, the Eggerian-Karpatian (i.e. late Oligocene - late early Miocene) foreland sediments are significantly thicker in the hanging wall than in the footwall. These foreland sediments downlap onto the hanging-wall post-rift megasequence to the SE and onlap and overlap the faulted post-rift units above the basement fault. Extensional displacement along this fault generated a breached forced fold affecting the post-rift and overlying foreland units. Moreover, the uppermost units immediately above the Mailberg fault are Karpatian-Badenian in age (i.e. latest early - earliest middle Miocene; Fig. 2). These units are folded into an open but slightly asymmetric anticline (referred to as the Mailberg Anticline) which lies above the regional elevation and displays a larger gently dipping back-limb and a shorter more steeply dipping forelimb (Fig. 7). In addition to this, a Badenian-age (i.e. early middle Miocene) coralline-algal reef was developed onto this anticline, surrounded by and interfingering with deeper-water siliciclastic-dominated facies (Mandic, 2004). 


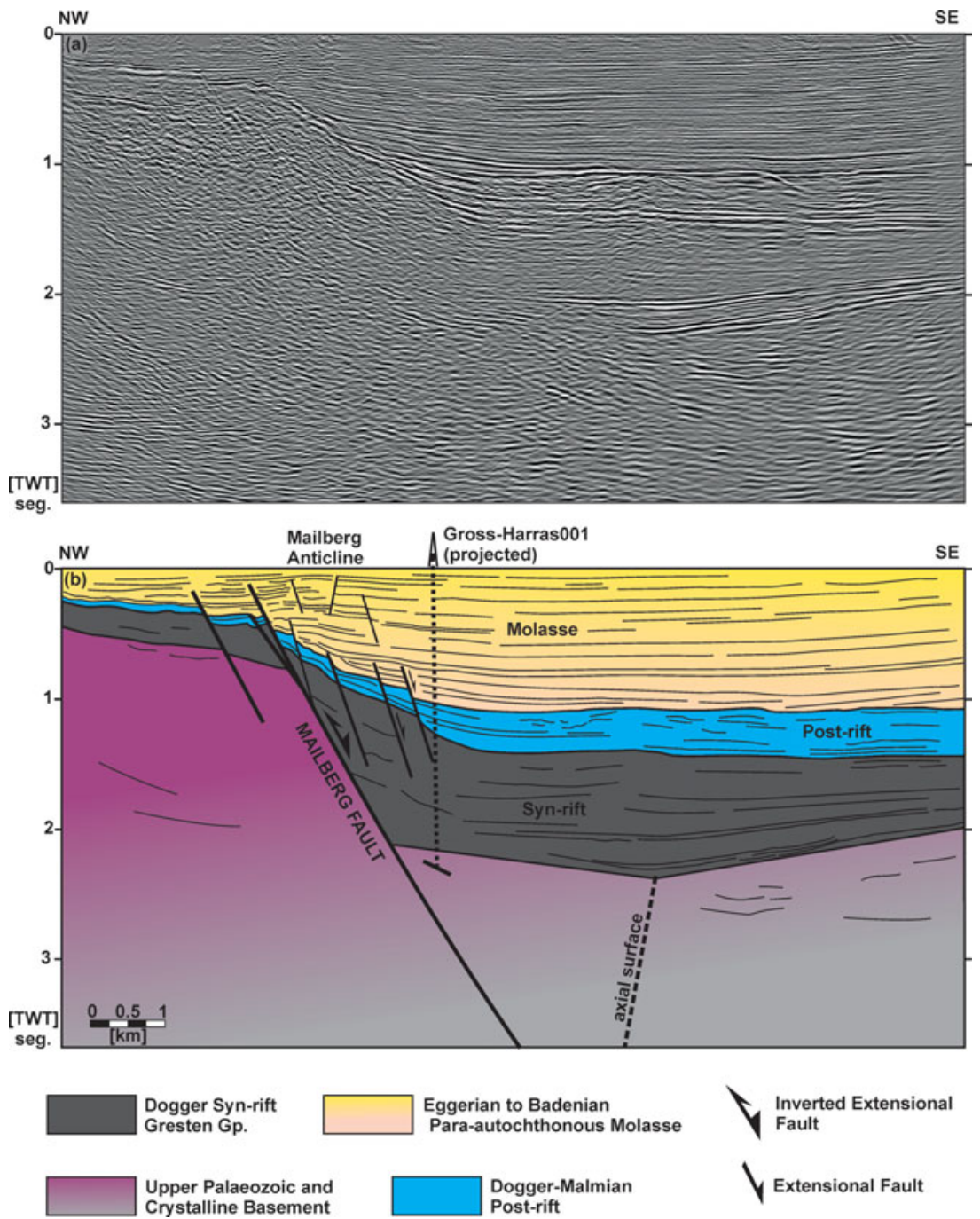

Figure 7. (Colour online) (a) NW-SE-striking time-migrated profile. (b) Geoseismic interpretation showing the Mailberg half-graben in the foreland region ahead of the thin-skinned thrust front. Note the extensional offset shown by the top of the basement and the post-rift megasequence. Note the thicker sections of syn-rift and Molasse basin strata in the hanging wall than in the footwall, and the erosion of the upper section of the post-rift megasequence in the elevated footwall. The Mailberg Anticline developed above the extensional fault shows a larger back-limb and a shorter forelimb. These features are indicative of thick-skinned positive inversion following an early Miocene extensional reactivation of the Jurassic Mailberg fault. See Figure 3 for location of the profile.

The calculated fault displacement profile for the top basement in the Mailberg fault displays two displacement minima at both ends of the fault, whereas the central portions of the fault display a rather uniform throw (Fig. 6a). Such a displacement profile is not in agreement with the commonly observed displacement profiles of extensional faults, where the displacement maximum is commonly located near the centre of the faults (e.g. Peacock \& Sanderson, 1991; Cartwright, Mansfield \& Trudgill, 1996; Willemse, Pollard \& Aydin, 1996). In this case, the central portion of the Mailberg fault is spatially coincident with the above-mentioned Mailberg Anticline. Based on the evidence provided, we interpreted that the Mailberg fault underwent two episodes of reactivation. The first was in extension during Eggerian-Karpatian time (i.e. late Oligocene - late Early Miocene), as shown by the extensional displacement of the post-rift units and thickness differences observed across the fault for the lower Miocene se- quences. This first extensional reactivation is therefore synchronous with the thin-skinned thrusting. It was followed by a later episode of shortening in Badenian times (i.e. earliest middle Miocene), responsible for the development of the Mailberg Anticline and the partial removal of the extensional displacement.

\section{4.b.2. The Altenmarkt fault}

The Altenmarkt fault is located just ahead of the thinskinned thrust front of the Alpine-Carpathian Junction (Fig. 8). This fault runs along-strike for at least $15 \mathrm{~km}$, dying out towards the NE where it is relayed by a system of two smaller SE-dipping rift faults; towards the SW, it continues out of the $3 \mathrm{D}$ cube (Fig. 5). This is also supported by the calculated fault displacement profiles for the top of the basement and the base of the postrift megasequence (Fig. 6b). This plot indicates that the fault is in net extensional displacement and that the 

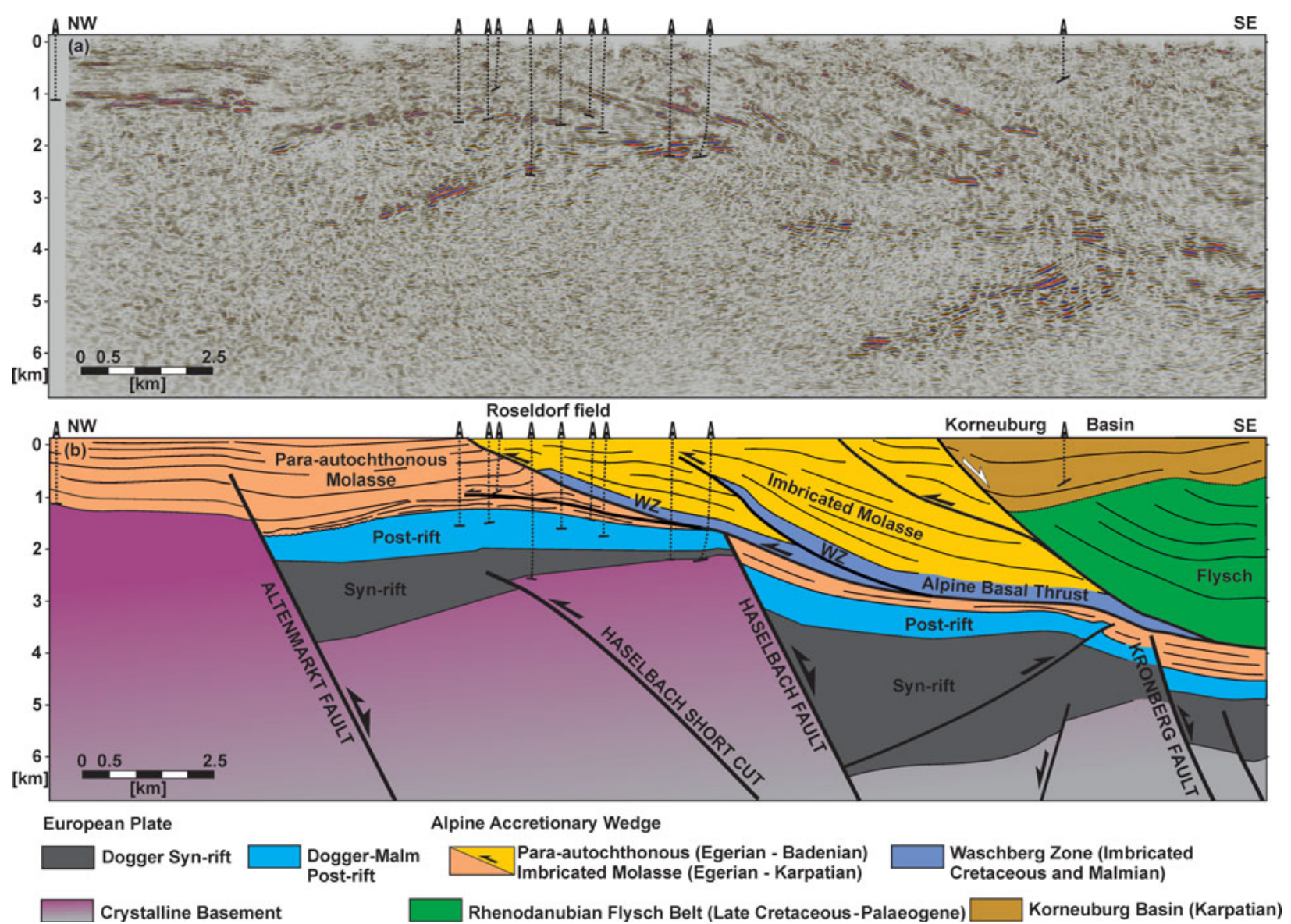

Figure 8. (Colour online) (a) NW-SE-striking depth-migrated seismic profile. (b) Geoseismic interpretation. The Altenmarkt fault locates ahead of the thin-skinned thrust front where the Roseldorf hydrocarbon field is located. Note extensional offset shown by the post-rift megasequence and the Para-autochthonous Molasse growth strata wedges indicative of Eggerian-Ottnangian (i.e. late Oligocene - early Miocene) extensional reactivation of the Altenmarkt and Haselbach faults. Positive inversion of the basement fault array is shown by open folding of the Altenmarkt hanging-wall strata, and the formation of a basement involved a shortcut fault and a backthrust emerging from the Haselbach fault. Gentle folding of the cover strata and thrust sheets above these inversion-related faults indicate that extensional reactivation of the basement fault array was followed by its positive inversion. See Figure 5 for location of the profile. WZ - Waschberg Zone.

displacement maximum is strongly shifted towards the SW. The Altenmarkt fault comprises several segments of differing orientation ranging from NNE- to NE-SWto $\mathrm{E}-\mathrm{W}$-striking. In addition, the fault is connected to a roughly NW-SE-striking fault that could be a transfer zone.

Seismic interpretation and well data indicate that the post-rift megasequence is missing to the west and SW on the footwall of the Altenmarkt fault, where Eggerian (i.e. late Oligocene - early Miocene) strata are unconformably overlying the top of the crystalline basement. The base of the post-rift megasequence is also considerably downthrown in the hanging wall of the fault. Seismic and fault displacement profiles show that the missing post-rift megasequence is spatially coincident with the fault segment that displays the largest throw values. In addition, the Eggerian - Karpatian (i.e. late Oligocene - late early Miocene) sequence is significantly thicker in the hanging wall than in the footwall, indicating that the extensional reactivation of the Altenmarkt fault during that time. Seismic evidence also suggests partial erosion of the post-rift section in the immediate hanging wall below these sediments. Extensional displacement along this fault decreases upwards by developing an extensional fault-propagation fold (Fig. 8).

The top of the crystalline basement in the hanging wall of the Altenmarkt fault is divided into two panels which are slightly separated by a low-angle offset (Fig. 8). The NW panel dips toward the fault more steeply than the SE panel. The units above this basement kink (i.e. syn-rift and post-rift megasequences and overlying Molasse basin sediments) are folded into a broad open anticline, above which the Roseldorf hydrocarbon field is located. This anticline and the low-angle offset affecting the top of the basement are interpreted to be related to a NW-directed basement-involved thrust fault (Figs 5e, 8). This thrust is interpreted as a footwall shortcut thrust (Badley, Price \& Backshall, 1989; Hayward \& Graham, 1989) emanating from and kinematically linked to the steeply dipping Haselbach fault. 


\section{4.b.3. The Haselbach fault}

The Haselbach fault is located in the middle of the 3D cube and runs in excess of $20 \mathrm{~km}$ along-strike below the thin-skinned thrust front. The Haselbach fault displays the largest observed throw values of the basement fault array, exceeding $4000 \mathrm{~m}$ for the top of the crystalline basement (Fig. 6c). In the section corresponding to the displacement maximum of the fault, the top of the crystalline basement dips towards the NW (i.e. towards the Haselbach fault), where extension is related to one large basement fault (Fig. 8). Towards the NE, seismic and well data indicate that the top of the basement is folded into a hanging-wall syncline; to the SW, the top of the basement displays a down-to-the-SE terraced geometry. Such terraced geometry is in agreement with the existence of several planar extensional faults (Fig. 9). The observed lateral variation in the geometry of the basement top of the hanging wall suggests a slightly kinked geometry for the Haselbach fault at depth, with the hanging-wall syncline developed for those layers with less extensional displacement and still above the fault kink (Xiao \& Suppe, 1992). The kink in the fault is not observed in the seismic data and should be located at greater depth. In addition, the base of the post-rift megasequence in the hanging wall is downthrown in excess of $1000 \mathrm{~m}$ (Figs $6 \mathrm{c}, 8,9$ ). Such extensional offset is also accompanied by a thick Eggerian-Ottnangian (i.e. late Oligocene - early Miocene) sedimentary wedge. Well and seismic data also indicate that the sedimentation of this sedimentary wedge is responsible for the partial erosion of the underlying post-rift section.

In cross-section, the base of the post-rift megasequence on the hanging wall of the Haselbach fault displays a subhorizontal attitude (Figs 8, 9). On map view (Fig. 5b), the base of the post-rift megasequence dips towards the NE (i.e. towards the Haselbach half-graben depocentre), indicating that its regional attitude relates to the inherited extensional architecture of the LAMB. To the SW, the post-rift section above the Haselbach fault is folded into an open anticline (Fig. 9). This anticline (referred to as the Stockerau Anticline) affects the autochthonous foreland units and the overlying imbricated foreland strata. To the east, the hanging-wall section is folded into an anticline with a large shallowly NW-dipping limb and a shorter SE-dipping limb (Figs 5e, 8). This anticline gently folds the overlying strata and structural units above the hanging wall. This structure is interpreted as related to a SE-directed backthrust nucleated from the Haselbach fault along the basal pre-rift to syn-rift section. According to the geometries described, the steeply dipping Haselbach fault seems to have acted as a buttress upon shortening (e.g. Butler, 1989), promoting the development of the basement-involved shortcut and hanging-wall backthrust.

\section{4.b.4. The Kronberg high and related extensional fault}

The Kronberg high locates to the eastern part of the 3D model (Fig. 5). This basement high strikes NE-
SW and corresponds to the elevated footwall of the NE-SW-striking Kronberg extensional fault (Figs 10, 11). The Kronberg fault runs along-strike for about $10 \mathrm{~km}$ and is relayed to the SW by another extensional fault (Fig. 5). The calculated fault displacement profile shows a displacement maxima located within the central part of the fault. At this position, extensional offsets for the top of the crystalline basement are in excess of $2 \mathrm{~km}$. The Kronberg high locates in the immediate footwall of the displacement maxima of this fault (Figs 5, 6d).

The high was drilled by the Kronberg T1 well, targeting the sub-thrust post-rift and syn-rift reservoir sections (Zimmer \& Wessely, 1996). The well drilled down to $4714 \mathrm{~m}$ through the imbricated units of the Flysch and Waschberg zones, and found Eggerian (i.e. late Oligocene - early Miocene) Molasse sediments on top of the syn-rift megasequence; the post-rift carbonate section (i.e. the reservoirs) were missed (Fig. 10). Fault displacement profiles calculated for the preserved base of the post-rift megasequence away from the footwall high indicate extensional offsets in excess of $1000 \mathrm{~m}$ (Fig. 6d). The fault displacement profile for the base of the post-rift displays a similar displacement distribution to that shown by the top of the crystalline basement. In addition to this, the Kronberg fault hanging wall displays a Molasse sedimentary wedge above the syn-rift and post-rift megasequences thicker than that drilled by the Kronberg T1 well. These observations suggest that the basal section of the post-rift megasequence on the Kronberg high was eroded by the footwall uplift related to the Eggerian-Ottnangian (i.e. late Oligocene - early Miocene) extensional reactivation of the Kronberg fault.

\section{4.b.5. The Höflein high and related fault system}

The Höflein high is located at the southern corner of the 3D model, about $10 \mathrm{~km} \mathrm{NNW}$ of the city of Vienna (Figs 3, 5) and beneath the Flysch Zone imbricates (Figs 9, 11, 12). Available well and seismic data indicate that the master basement fault extends for as much as $12 \mathrm{~km}$ along-strike and displays two important changes in strike: from NNE- to E-W to NE-SWstriking (Fig. 5). These fault segments are steeply dipping and display a slightly concave-upwards geometry. The Höflein high corresponds to the elevated footwall of the E-W-striking fault segment (Fig. 5); in addition, the hanging wall of this fault segment displays the thickest syn-rift depocentre of the Höflein half-graben (Fig. 5e).

At this position, the footwall of the Höflein fault hosts the most important gas and condensate field in the sub-thrust region of Lower Austria (Janoscheck, Malzer \& Zimmer, 1996; Zimmer \& Wessely, 1996; Sachsenhofer et al. 2006). This hydrocarbon field produces from the (Para)-autochthonous post-rift carbonates and the syn-rift siliciclastic section in a footwall four-way-dip closure (Figs 5, 13). The E-W orientation of the footwall basement high significantly departs 

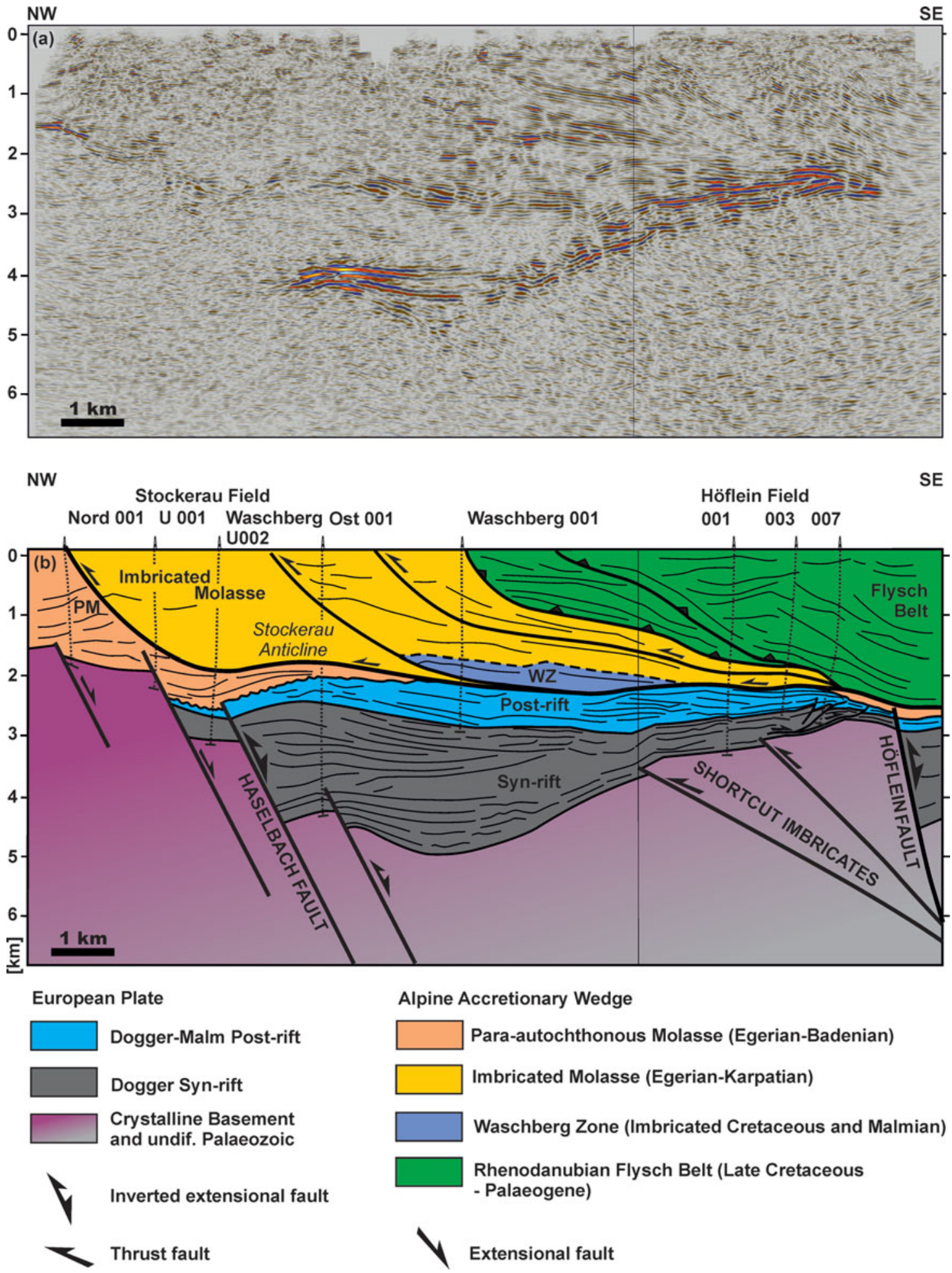

Figure 9. (Colour online) (a) NW-SE-striking depth-migrated seismic profile through the Stockerau and Höflein fields. (b) Geoseismic interpretation. Note the energetic reflections given by the pre-rift units near the top of the crystalline basement and those above corresponding to the post-rift carbonates. The Eggerian-Ottnangian (i.e. late Oligocene - early Miocene) wedges above the Haselbach and Höflein faults indicate the timing of extensional reactivation of the basement fault array. Positive inversion followed as indicated by the development of the Stockerau Anticline, the elevated Höflein footwall and the associated folding of the overlying thrust sheets. See Figure 5 for location of the profile. WZ - Waschberg Zone; PM - Para-autochthonous Molasse.

from the regional NE-SW-striking basement fault array trend. The Höflein high is slightly offset by a NW-SEstriking extensional fault, with its downthrown block located to the SW. The Höflein extensional fault could be correlated to the NE with the Kasernberg fault, but the lack of 3D seismic data avoided this correlation (Fig. 5). At the footwall high, the crystalline basement is located at c. $2500 \mathrm{~m}$ below mean sea level. This is about $2000 \mathrm{~m}$ above the top of the crystalline basement drilled by the Kronberg T1 well (Fig. 11). As 

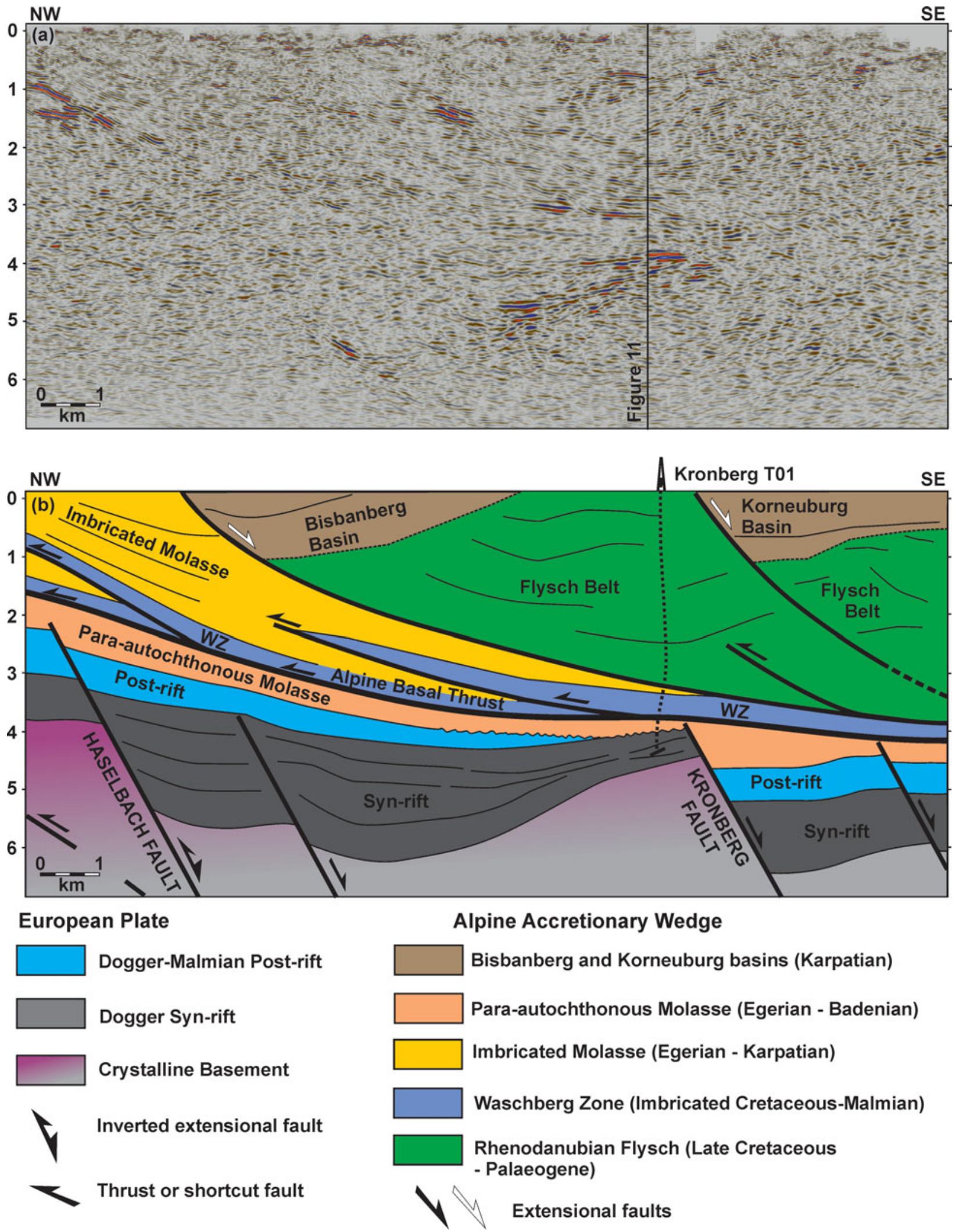

Figure 10. (Colour online) (a) NW-SE-striking depth-migrated seismic profile along the Kronberg high. (b) Geoseismic interpretation. Kronberg T01 well drilled Eggerian-Ottnangian (i.e. late Oligocene - early Miocene) sediments unconformably overlying the basal syn-rift section. Note the missing post-rift onto the Kronberg fault footwall. The Waschberg Zone and basal Alpine thrust consist of imbricated Cretaceous and Malmian units scrapped off from the underlying autochthonous units. WZ - Waschberg Zone. 

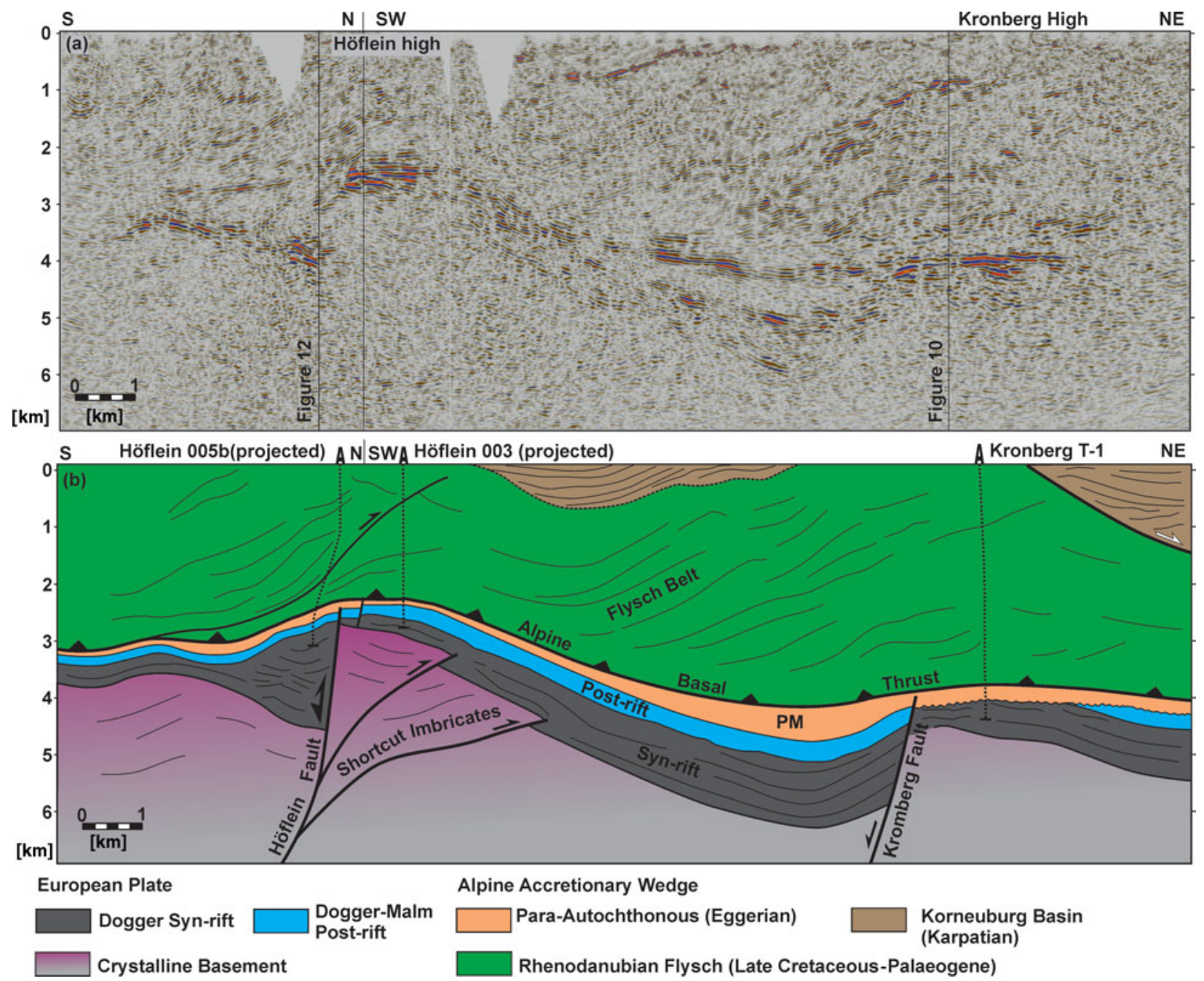

Figure 11. (Colour online) (a) Composite depth-migrated section from the Höflein field to the SW and the Kronberg high to the NE. (b) Geoseismic interpretation. Energetic reflectors on the Höflein high correspond to the post-rift carbonates and underlying synand pre-rift siliciclastics. On the Kronberg high the high-energy reflections correspond to the Autochthonous Molasse unconformably overlying the syn-rift units; post-rift carbonates are missing. Seismic and well data show the substantially higher elevation of the basement in the Höflein high than in the Kronberg high, as well as the folding of the overlying imbricates of the Flysch Zone. The basal thrust zone is constituted by imbricated Malmian, Cretaceous and Eggerian (i.e. late Oligocene) sediments. Dipping reflections within the Rhenodanubian Flysch indicate a transport direction oblique to the seismic profile. See Figure 5 for location of the profile. PM - Para-autochthonous Molasse.

previously stated, the whole post-rift section is preserved at Höflein high, but not at Kronberg high (Fig. 11). Regarding the hanging wall, the basement top is folded into a plunging NE-SW-striking syncline and anticline pair (i.e. slightly oblique to the trend of the Höflein fault).

In order to illustrate the geometry of the Höflein high and related fault systems, two NW-SE-striking crosssections (Figs 9, 12) and a composite NE-SW-striking cross-section (Fig. 11) were made (see Fig. 5a for location). The first of these cross-sections goes from the Stockerau field to the NW to the Höflein field to the SE, and shows the elevated footwall of the Höflein extensional fault (Fig. 9). At this position, the Höflein high is characterized by the prominent footwall reflections of the post-rift carbonates. To the SE, these reflections disappear and locate on the Höflein's downthrown hanging wall. On the footwall, the post-rift carbonates are off- set and imbricated several times by a series of NESW-striking small-displacement backthrusts (Figs 5, 9). The top of the crystalline basement is folded into two panels which relate to two roughly NE-SW-striking basement-involved reverse faults emerging from the Höflein extensional fault (Figs 5, 9b). Displacement and folding associated with these reverse faults are, at least partially, responsible for the high elevation of the Höflein high.

Further to the SW, a section across the Höflein fault away from the elevated footwall displays a thick package of subhorizontal reflections at $3.5 \mathrm{~km}$ depth which are unconformably overlain by SE-dipping reflections (Fig. 12). Similarly, these relationships are shown in a roughly perpendicular section (Fig. 11). Well data from the recently drilled well Höflein $5 \mathrm{~b}$ (OMV, unpub. report, 2013) indicate that these thick subhorizontal reflections belong to the syn-rift Gresten Group, whereas 

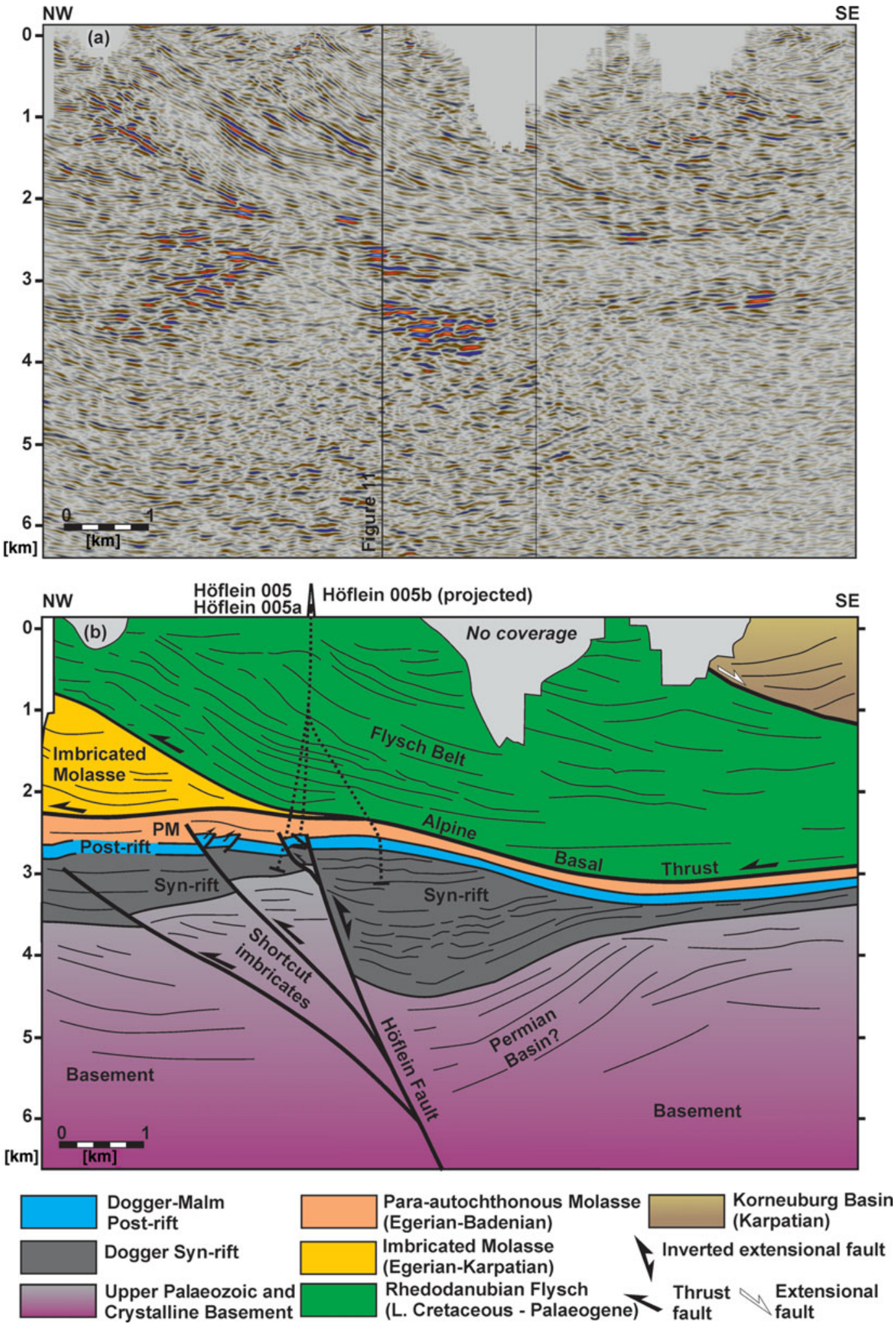

Figure 12. (Colour online) (a) NW-SE-striking depth-migrated seismic profile SW of the elevated Höflein footwall. (b) The geoseismic interpretation shows a reactivated extensional fault with two associated basement-involved shortcut faults interpreted as harpoon or arrowhead structure. This structure is responsible for the imbrication of the basement and the syn-rift section and the folding of the overlying cover and thrust sheets. Small displacement thrusts and backthrusts repeat the carbonate reservoir section.

the dipping reflections immediately above belong to the post-rift reservoir section. Significantly thicker Eggenburgian-Ottnangian (i.e. early Miocene) strata in the hanging wall than in the footwall were found. At this position, the post-rift carbonates lie slightly above the regional elevation (Fig. 6e). Well data also indicate a tectonic repetition of the Höflein Formation in the footwall of the Höflein extensional fault (Fig. 12b). In addition to this, regional elevation also indicates the local repetitions of the syn-rift footwall section to the 


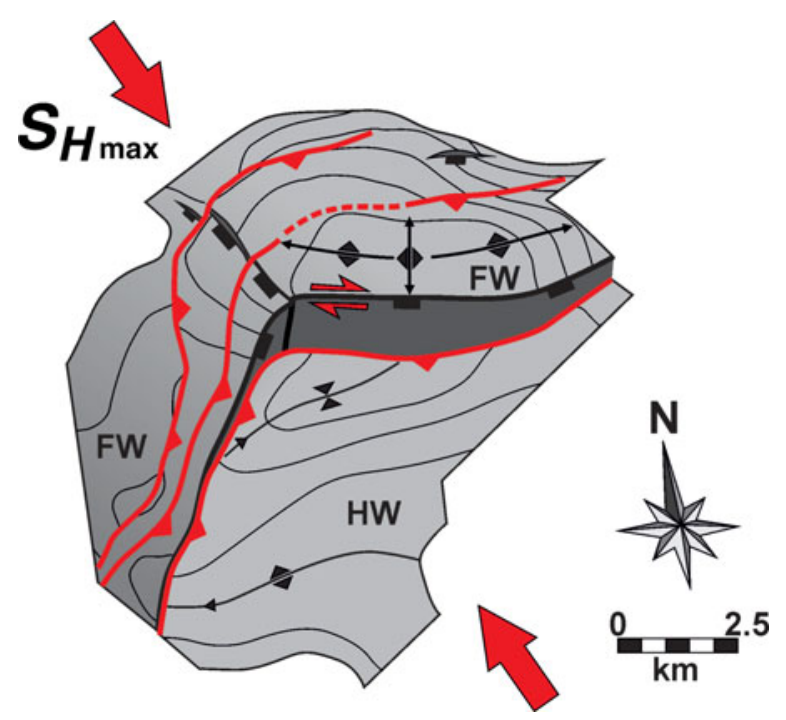

Figure 13. (Colour online) Conceptual 3D model of the Höflein high based on the interpretation of 3D seismic. The surface represents the top of the crystalline basement. Extensional faults are depicted in black, whereas inversion-related thrust faults and reactivated faults are shown in red. The favoured interpretation is a complex harpoon structure related to the mild right-lateral transpressive inversion of a non-rectilinear steeply dipping extensional fault (i.e. Höflein fault) and the associated formation of basement-involved footwall shortcuts. HW - hanging wall; FW - footwall.

NW (Fig. 12). Above the folded post-rift carbonates, the reflections belonging to the Flysch Zone imbricates and the Basal Alpine Thrust are folded into an open anticline (Fig. 12). These cross-cutting relationships provide strong time constraints on the structural evolution of the Höflein field in particular, but also for the studied area.

Fault displacement profiles were calculated for the top of the crystalline basement and the base of the post-rift megasequence (Fig. 6e). The Höflein extensional fault shows a dramatic change in the alongstrike throw distribution, as also reflected in the synrift isopach map (Fig. 5e). This sharp change in throw and syn-rift sediment thickness is coincident with the change in the strike of the extensional fault from the E-W-striking segment to the NNE-SSW-striking segment. Based on the constructed sections and the 3D structural model, the Höflein field is interpreted as a complex harpoon structure (Badley, Price \& Backshall, 1989; Hayward \& Graham, 1989; Buchanan \& McClay, 1991) consisting of a mildly inverted extensional fault with two basement-involved footwall shortcut faults, and a series of small-displacement thrust and backthrusts which are responsible for the locally observed repetitions of the reservoir carbonate section. According to the geometries described it is suggested that the Höflein extensional fault acted as a buttress upon shortening, promoting the development of the basement-involved shortcut faults and the secondary backthrusts.

\section{Discussion and concluding remarks}

\section{5.a. Summary of observations: stress-fields and timing constraints}

In our work we document several reactivation episodes of the Lower Austria basement fault array in both extensional and shortening modes. The LAMB basement fault array is represented by thick Doggerian wedges related to the rifting and opening of the Alpine Tethys, but some of these basement-involved faults can be as old as of late Palaeozoic age as suggested by borehole data (Wessely, 2006). The LAMB basement-involved faults underwent a first episode of extensional reactivation as shown by the large extensional offsets of the postrift megasequence and thick (i.e. in excess of $1000 \mathrm{~m}$ thick) Eggerian-Karpatian (i.e. late Oligocene - late early Miocene) extensional growth wedges. Biostratigraphically constrained well tops and seismic evidence indicate that the extensional reactivation of the basement faults was synchronous with the development of the thin-skinned FTB and its flexural foreland basin. Broadly speaking, the growth wedges young towards the NW, from Eggerian-Karpatian (i.e. late Oligocene late early Miocene) age. This provides evidence for the forwards migration of the basement fault array extensional reactivation as the thin-skinned orogenic wedge overrode the subducting European lower plate.

Afterwards, selective mild positive tectonic inversion of the basement fault array took place. This positive inversion event is represented by the mild reactivation upon shortening of several basement-involved faults or fault segments, and the associated folding of the cover. The positive inversion is also shown by a suite of new structures including basement-involved footwall shortcut thrusts (i.e. Haselbach shortcut and Höflein shortcuts) and second-order thrusts (Haselbach backthrust and Höflein backthrusts). The NE-SW orientation of the inversion-related faults is parallel to that of the basement fault array (Fig. 5c, d, e) and suggests roughly coaxial (at least locally) stress fields for the Jurassic rifting and the late Alpine shortening (i.e. NW-directed). In this sense, and in the absence of large fluid overpressures (e.g. Sibson, 1983, 1985, 1990), the generation of new moderately dipping reverse faults is mechanically favoured rather than reactivating the steeply dipping pre-existing basement faults. Moreover, the formation of the footwall shortcuts would have been facilitated by the kinked nature of the basement faults (i.e. Haselbach fault).

The Höflein high is the most important hydrocarbon field in the sub-thrust region of Lower Austria and previous works interpreted its origin as related to purely extensional tectonics (Zimmer \& Wessely, 1996). In this work, we propose an alternative interpretation based on a re-interpretation of data where the Höflein high is a complex harpoon structure associated with the inversion of a non-rectilinear extensional fault system (Figs 5, 13). As shown by 3D seismic, well and gravity data, the Höflein high is located nearby the margin of the LAMB, in close proximity to the rigid 
Bohemian crystalline massif (Figs 3, 4c) and the Vienna Basin boundary. This fact also suggests that the Bohemian crystalline massif behaved as a rigid buttress promoting the mild inversion of the extensional fault system and the formation of footwall shortcut structures and backthrusts. Whether the positive inversion of the basement fault array was associated with the late stages of the Miocene NW-directed Alpine-Carpathian shortening or the east-directed lateral extrusion is arguable. Present-day seismicity shows the absence of thrust-faulting earthquakes and points to oblique transpressional kinematics (Reinecker \& Lenhardt, 1999).

These authors also discuss stress orientation data from borehole breakouts in the Höflein field, indicating large dispersion in the orientation of the principal horizontal compressive stress (i.e. $S H_{\text {max }}$ or $\sigma_{1}$ ), from NNE-SSW- to NW-SW- to NE-SW striking. This is most probably related to two fundamental factors: (1) these borehole break-outs relate to the present-day stress field, which does not need to be the same as the prevailing Miocene stress field; and (2) stress deviations between the local orientation of the $\mathrm{SH}_{\text {max }}$ and the average regional stress orientation (Rebaï, Philip \& Taboada, 1992; Zoback, 2010). The non-rectilinear Höflein half-graben was probably preferentially reactivated than the other basement-involved faults, as the E-W-striking fault plane was not perpendicular to the prevailing subhorizontal NW-directed Alpine principal compressive stress $\left(\mathrm{SH}_{\max }\right.$ or $\left.\sigma_{1}\right)$ and not containing the intermediate principal stress $\left(\mathrm{SH}_{\mathrm{int}}\right.$ or $\left.\sigma_{2}\right)$, as fault reactivation is partly dependent on the magnitude of $\sigma_{2}$ (Jaeger \& Cook, 1979; Zoback, 2010). A NW-directed shortening would have reactivated the E-W-striking segment of the Höflein extensional fault in right-lateral transpressive kinematics. On the other hand, if the inversion of the extensional fault system was related to the lateral E-directed extrusion, the Höflein high would correspond to a restraining bend resulting from left-lateral transpression. In this sense, the orientation, shape and transport direction of the footwall shortcuts and the backthrusts (Fig. 5d, e) fit better with the rightlateral transpressive inversion model in relation to the regional NW-directed shortening.

In the absence of syn-inversion growth strata in the sub-thrust region, relative time constraints can be inferred from the observed cross-cutting relationships. The final activity of the thin-skinned thrust system in the studied area is constrained by the latest early Miocene (i.e. Karpatian) thrust front and piggy-back basins growth strata (Decker \& Peresson, 1996; Hölzel et al. 2010; Beidinger \& Decker, 2014) which is also coincident with the initial infill of the Korneuburg, FohnsdorfSeckau and related pull-apart basins developed on top of the FTB (i.e. Ratschbacher et al. 1991; Strauss et al. 2001; Harzhauser et al. 2002; Fig. 3b). The thickskinned inversion of the sub-thrust basement fault array (i.e. Höflein) should therefore be as old as of Karpatian (latest early Miocene) age, whereas in the foreland (i.e. Mailberg) the Badenian facies distribution (Mandic,
2004) suggests a slightly younger age of inversion (i.e. earliest middle Miocene). This is in agreement with the progressive, although very fast, forwards migration of thick-skinned basement fault reactivation.

\section{5.b. The role of the basement in the Alpine-Carpathian FTB development}

The basement of the Alpine-Carpathian FTB presents a general tilting towards the south underneath the Alpine-Carpathian edifice (Wessely, 1987). Deep exploration wells have indicated a differing nature for the crystalline basement of the LAMB and that of the Bohemian Spur. The LAMB sits on crystalline and metasedimentary basement of Moravo-Silesian affinity, whereas the Bohemian Spur is constituted by rigid crystalline basement of Moldanubikum affinity (Kröll \& Wessely, 2001; Wessely, 2006). These different basement domains were assembled during the Late Palaeozoic Variscan Orogeny and their boundary corresponds to a major orogenic suture (Neubauer \& Handler, 1999).

Lankreijer et al. (1999) defined several thermolithospheric domains of contrasting equivalent elastic thickness (EET) and rheology for the Bohemian and Alpine-Carpathian domains. According to these authors, the Bohemian domain is represented by extreme values of lithospheric strength and large EET, whereas the inherited Jurassic European continental margin is characterized by significantly lower values. As suggested by Reinecker \& Lenhardt (1999), such differing basement nature and associated rheological contrasts controlled the development and architecture of the Upper and Lower Austria Mesozoic Basins, the subsequent development of the Alpine-Carpathian FTB and probably that of the 'successor' middle-late Miocene basins.

More recently, Beidinger \& Decker (2014) have shown that the thin-skinned thrust front in the AlpineCarpathian Junction parallels the $-1000 \mathrm{~m}$ isoline (i.e. metres below mean sea level), and that the Bohemian Spur probably generated a buttressing effect that limited the forwards thrust propagation and led to generalized out-of-sequence thrusting. The present-day stress field and the recent earthquake distribution also indicate a strong basement control of the Bohemian massif, where the highest observed seismicity is located in its southernmost tip and displays a radial stress configuration (Reinecker \& Lenhardt, 1999). The Alpine Molasse basin drastically changes in width from west to east (Andeweg \& Cloethigh, 1998), forming two welldeveloped thrust salients with wide foreland basins in the Upper Austria and the Polish Carpathians regions. On the contrary, the Alpine-Carpathian Junction represents a recess, where the foreland basin is $c .9 \mathrm{~km}$ wide (Fig. 1). The observed lateral variation in the width of the Molasse Basin correlates with the degree of tilting of the foreland region and therefore with a lateral change in the EET (Andeweg \& Cloetingh, 1998). 
5.c. Possible controls on crustal coupling and geodynamic implications

Early orogenic shortening in the Alpine-Carpathian Junction was accommodated by shallow flat-dominated thin-skinned tectonics coeval with extension in the foreland plate. Late orogenic shortening was however accommodated by the reactivation of a deeper rampdominated thick-skinned system prograding beneath and ahead of the thin-skinned thrust front. Similar structural styles and timing relationships have recently been reported to the ENE of the studied area in the Western Carpathians (e.g. Castellucio et al. 2015) and in other collisional settings such as Taiwan, Western Alps, French Pyrenees (e.g. Lacombe \& Mothereau, 2002) or the Andes (e.g. Carrera \& Muñoz, 2013), among others (e.g. Cooper, 2007).

The reasons for a change from initial extension in the foreland to generalized crustal coupling, shortening and late widespread erosion and extension in the Alpine-Carpathian Junction must be the result of large, lithospheric-scale processes. Based on seismic and tomographic studies, Kissling (1993) and later Lippitsch, Kissling \& Ansorge (2003) concluded that a lithospheric slab beneath the Western and Central Alps is present, and probably connected to some point to the European continental lithosphere. However, in the Eastern Alps a high-velocity body corresponding to a subvertical to steeply NE-dipping subducted lithosphere has been interpreted (Lippitsch, Kissling \& Ansorge, 2003). More recent works have indicated that a detached European slab might still be connected to the lithosphere that is still in place in the Central Alps and might also be connected to a slab graveyard further to the east, at the depth of the upper mantle transition zone (e.g. Bianchi, Miller \& Bokelmann, 2014; Qorbani, Bianchi \& Bokelmann, 2014).

In either case, subduction and related bending of the lower plate seems to be - at least partially - responsible for the syn-thrusting Eggerian-Karpatian (i.e. late Oligocene - late early Miocene) extension accommodated by the reactivation of the foreland and sub-thrust basement fault array (Fig. 14a). The curvature radii and the thickness of the bending plate would have controlled the amount of extension along the outer arc of the plate (e.g. Ramsay, 1967; Turcotte \& Schubert, 1982; Twiss \& Moores, 1992; Fig. 14b). An important component of the observed extension could also relate to the retreat of the subducting lithospheric slab as a result of slab-pull forces, a process formerly proposed for the Carpathian arc (e.g. Decker \& Peresson, 1996; Linzer, 1996) and more recently for the central region of the European Alps (e.g. Schlunegger \& Kissling, 2015). The reported high lateral gradient of EET from the rigid Bohemian massif to the significantly softer Jurassic continental margin seems to be the fundamental cause of the large degree of bending needed to explain the observed extension.

This high EET gradient is also supported by the narrow foreland basin of the Alpine-Carpathian Junc- tion (Fig. 1). A SE-dipping deep detachment is therefore needed to explain the extension accommodated by the reactivation of the basement fault array (e.g. Bradley \& Kidd, 1991). A similar detachment beneath the Western-Central Alps foreland basin has also been proposed from the TRANSALP seismic profiling (TRANSALP Working Group, 2002) and field studies (e.g. Butler, 1989; Gillcrist, Coward \& Mugnier, 1987). Synchronously, widespread out-of-sequence thrusting (e.g. Beidinger \& Decker, 2014) in the extremely flexed region was probably a response of the prowedge to compensate the sinking of the foreland by regaining relief whereas in the platform, out-of-sequence thrusting was favoured by the buttressing effect of the rigid foreland and the foreland pinch-out of the efficient Mikulov Formation detachment. In addition, thrust loading and formation of a retrowedge seem likely given the strong shortening recorded by tight folds in the basement of the Vienna Basin as well as S-verging folds in the Northern Calcareous Alps (e.g. Grünbach syncline) west of the Vienna Basin (Wessely, 2006).

We propose that deep-seated processes affecting the European slab (Fig. 14c) during the final stages of collision are the trigger mechanisms to explain the general uplift of the area as evidenced by landscape evolution, changes in the drainage and subsidence patterns, and the observed shortening styles (e.g. Fodor, 1995; VonBlanckenburg \& Davies, 1995; Neubauer, Genser \& Handler, 1999; Wessely, 2006; Genser, Cloetingh \& Neubauer, 2007; Qorbani, Bianchi \& Bokelmann, 2014; Legrain et al. 2015). A large-wavelength rebound is well documented by Andeweg \& Cloetingh (1998) in the Molasse Basin of western Austria, whereas in the studied area such uplift is demonstrated by the presence of Karpatian-age kilometre-scale canyon incisions (e.g. Dellmour \& Harzhauser, 2012). This broad uplift is also supported by thermochronological and field studies in the Western Carpathians (e.g. Danišík et al. 2010; Mazzoli et al. 2010; Zattin et al. 2011; Anczkiewicz, Środoń \& Zattin, 2013; Andreucci et al. 2013, 2015; Castelluccio et al. 2015). The most probable candidates for such deep-seated processes are either oceanic slab roll-back and subsequent break-off, or delamination of the tectonically thickened European lithosphere (see Magni et al. 2013). These processes probably started around Karpatian time (e.g. Dellmour \& Harzhauser, 2012), but their effects protracted as shown by foreland subsidence analysis (e.g. Genser, Cloetingh \& Neubauer, 2007) and the ages of calc-alkaline (20 $11 \mathrm{Ma})$ and late alkaline magmatic series (9-1 Ma), indicating a transition from crustal contaminated magmas to asthenosphere-derived magmas generated by lithosphere extension, respectively (e.g. Embey-Isztin et al. 1993; Nemcok et al. 1998; Seghedi et al. 2004).

The fast rebound following the slab break-off (or delamination) most probably created an excessive topographic load along with drastic changes in the stress regime and high levels of shortening (e.g. Cloetingh et al. 2004; Genser, Cloetingh \& Neubauer, 2007). We propose that the Alpine-Carpathian tectonic wedge 
(a)

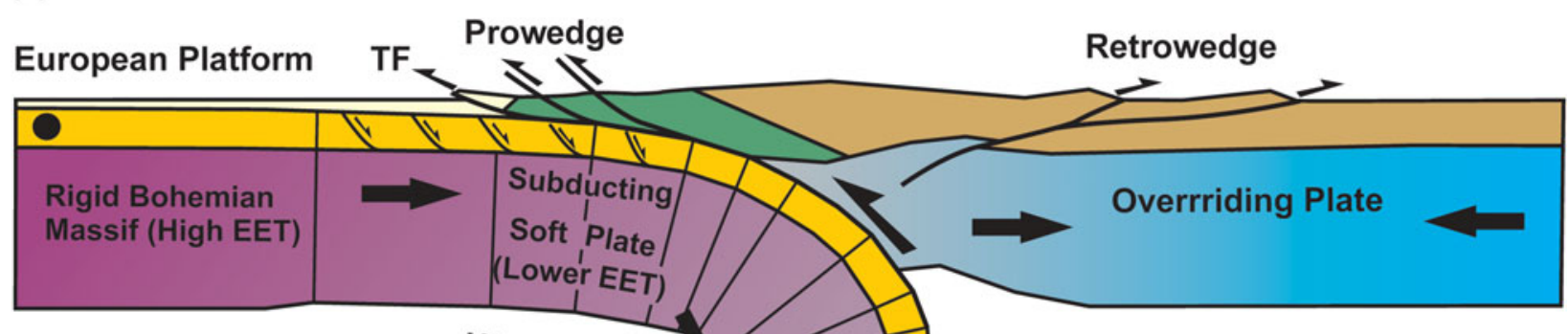

(b)

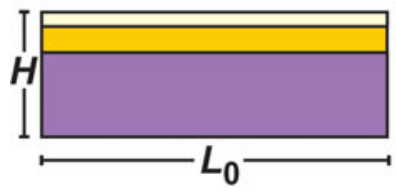

High Bending Degree

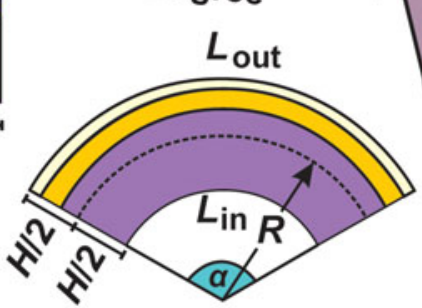

$\varepsilon_{\text {outer arc }}=\frac{L_{\text {out }}-L_{0}}{L_{0}}=\frac{\left(R+\frac{H}{2}\right) \alpha-R \alpha}{R \alpha}=\frac{H}{2 R}$
TF: Thrust Front

- Strain-ellipsoids

Bending and Slab Pull: Lower Plate Stretching

Prowedge Thickens by Out-of-Sequence Thrusting

(c)

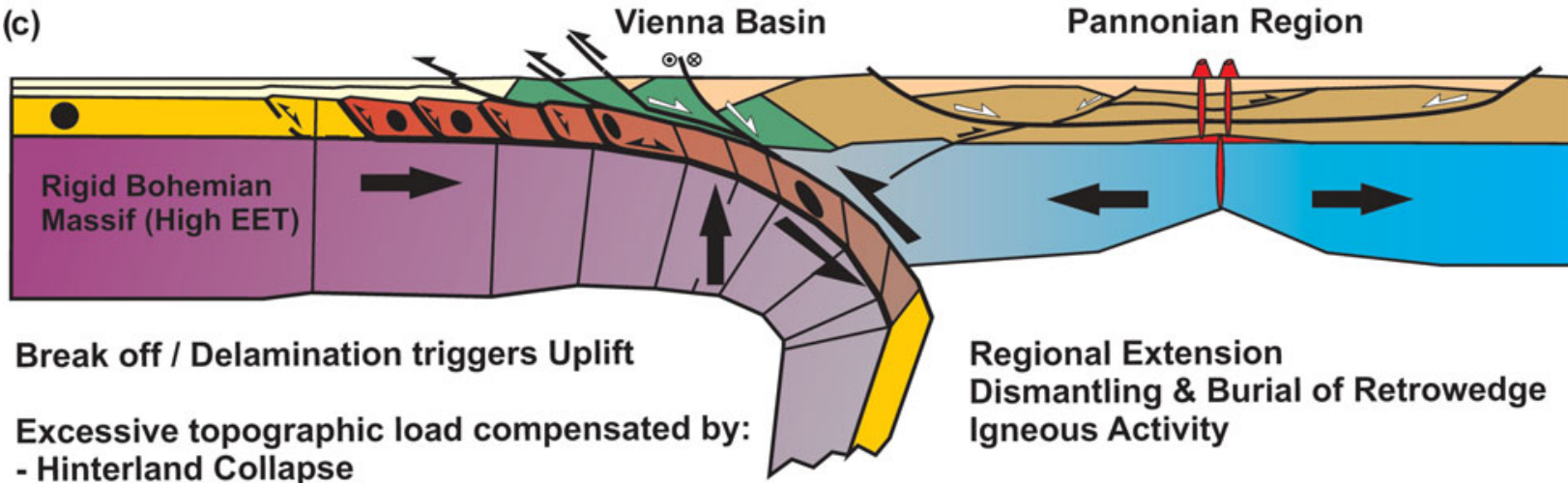

- Activation of Prowedge Deep Detachment

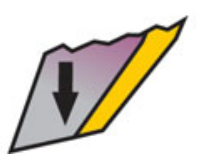

Figure 14. (Colour online) Lithospheric cross-section of the early Miocene collision represented by a subducting lower plate (left) being overridden by an upper plate (right). (a) The sharp transition from an extremely strong and rigid Bohemian massif to the softer Jurassic continental margin favours the acute bending of the lower plate, enhanced by the downward pull of the subducting slab. (b) Bending of a plate leads to the extension of the outer arc and contraction in the inner arc following the given equation. (c) Present-day lithospheric sketch. Slab break-off (or delamination of the orogenically thickened European lithosphere) triggered regional uplift (starting around Karpatian times in the studied area) and the associated excessive topographic load is compensated by basin inversion in the foreland and sub-thrust and the collapse of the hinterland summits. The retrowedge depicted in (a) has been dismantled by the middle-late Miocene regional extension and buried beneath the successor basins.

reacted by two mechanisms. (1) The reactivation of a deep detachment and the basement-involved extensional faults in the prowedge (i.e. basin inversion in the sub-thrust and in the foreland), with the subsequent broadening of the orogen. Basement shortening was most probably accommodated by a combination of distributed deformation in the crystalline basement and discrete heterogeneous simple shear along the deep de- tachment. (2) This was followed by the collapse of the hinterland orogenic edifice as represented by the opening of the Korneuburg, Vienna, Danube and Pannonian basins. Independently of the dominant strike-slip or oblique-slip activity of the Vienna Basin bounding faults (i.e. Steimberg and Mur-Mürz faults), these faults were key structural elements for the dismantling of the orogenic edifice. The transtensional dismantling 
around the Vienna Basin might have been enhanced by the shape of the Bohemian Massif foreland buttress.

A similar evolution has recently been proposed for the Western Carpathians and the associated Sub-Trata fault and its hanging-wall Liptov Basin (e.g. Castellucio et al. 2015). In this sense, the 'missing' retrowedge (Fig. 14c) has been extended and buried beneath the thick sedimentary cover of the middle-late Miocene basin systems. Once the topographic load was reduced, the thrust system shut off. The collapse of the orogenic wedge was ultimately driven by subduction processes (i.e. roll back, retreat and final break-off or lithosphere delamination).

Acknowledgements. This is a contribution of the Institut de Recerca Geomodels and the Geodinàmica i Analisi de Conques research group (2014SGR467SGR) from the Agència de Gestió d'Ajuts Universitaris i de Recerca (AGAUR) and the Secretaria d'Universitats i Recerca del Departament d'Economia i Coneixement de la Generalitat de Catalunya. PG acknowledges financial support from OMV Exploration and Production GmbH (Project FBG307451). OMV Exploration and Production $\mathrm{GmbH}$ is also thanked for data supply and permission to publish. Andreas Beidinger, Ralph Hinsch and Herwig Peresson from OMV Exploration and Production $\mathrm{GmbH}$ are thanked for their comments and suggestions on the very first version of the manuscript. The final version of this paper greatly benefited from the thoughtful revisions by two anonymous reviewers. We would like to extend our appreciation to the editors for allowing us to publish in this special volume. Petrel modelling software by Schlumberger and Skua modelling software by Paradigm were used to build the 3D geological models. Move restoration software was used for cross-section construction.

\section{References}

Allen, P. A. \& Allen, J. R. 2005. Basins due to flexure. In Basin Analysis. Principles and Applications, 2nd edn. (eds P. A. Allen \& J. R. Allen), pp. 116-66. Malden, MA: Blackwell Publishing.

Anczkiewicz, A. A., Środoń, J. \& Zattin, M. 2013. Thermal history of the Podhale Basin in the internal Western Carpathians from the perspective of apatite fission track analysis. Geologica Carpathica 64, 141-51.

AndeweG, B. \& Cloetingh, S. 1998. Flexure and 'unflexure' of the North Alpine German-Austrian Molasse Basin: constraints from forwards tectonic modelling. In Cenozoic Foreland Basins of Western Europe (eds A. Mascle, C. Puigdefàbregas, H. P. Luterbacher \& M. Fernàndez), pp. 403-22. Geological Society of London, Special Publication no. 134.

Andreucci, B., Castelluccio, A., Corrado, S., JANKOWSKI, L., Mazzoli, S., SZANiaWSKI, R. \& ZATTIN, M. 2015. Interplay between the thermal evolution of an orogenic wedge and its retro wedge basin: an example from the Ukrainian Carpathians. Geological Society of America Bulletin 127, 410-27.

AndreucCI, B., CAstelluccio, A., JANKOWSKI, L., Mazzoli, S., Szaniawski, R. \& ZatTin, M. 2013. Burial and exhumation history of the Polish Outer Carpathians: discriminating the role of thrusting and post-thrusting extension. Tectonophysics 608, 866-83.

ARZMÜLler, G., BuChtA, S., RAlbovsKÝ, E. \& Wessely, G. 2006. The Vienna Basin. In The Carpathians and their Foreland: Geology and Hydrocarbon Resources. (eds J. Golonka \& F. J. Picha), pp. 191-204. American Association of Petroleum Geologists, Memoir no. 84.

Badley, M. E., Price, J. D. \& BaCkshall, L. C. 1989. Inversion, reactivated faults and related structures: seismic examples from the southern North Sea. In Inversion Tectonics (eds M. A. Cooper \& G. D. Williams), pp. 201-19. Geological Society of London, Special Publication no. 44.

Beaumont, C., Muñoz, J. A., Hamilton, J. \& Fullsack, P. 2000. Factors controlling the Alpine evolution of the central Pyrenees inferred from a comparison of observations and geodynamical models. Journal of Geophysical Research 105(B4), 8121-45, doi: 10.1029/1999JB900390.

BeIDINGER, A. \& DECKER, K. 2014. Quantifying Early Miocene in-sequence and out-of-sequence thrusting at the Alpine-Carpathian junction. Tectonics 33, 222-52.

BiAnCHI, I., Miller, M. \& BoKELMANN, G. 2014. Insights on the upper mantle beneath the Eastern Alps. Earth and Planetary Science Letters 403, 199-209.

BRADLEY, D. C. \& KIDD, W. S. F. 1991. Flexural extension of the upper continental crust in collisional foredeeps. Bulletinof the Geological Society of America 103, 141638.

Brown, D., Álvarez-Marrón, J., Schimmel, M., Wu, Y. M. \& CAMANNI, G. 2012. The structure and kinematics of the central Taiwan mountain belt derived from geological and seismicity data. Tectonics 31 TC5013, doi: 10.1029/2012TC003156.

BuChanan, P. G. \& MCClay, K. R. 1991. Sandbox experiments of inverted listric and planar fault systems. Tectonophysics 188, 97-115.

Burov, E. B. \& DiAmENT, M. 1995. The effective elastic thickness $\left(\mathrm{T}_{\mathrm{e}}\right)$ of continental lithosphere: what does it really mean? Journal of Geophysical Research $\mathbf{1 0 0}$, 3905-27.

BUTLER, R. W. H. 1989. The influence of pre-existing basin structure on thrust system evolution in the Western Alps. In Inversion Tectonics (eds M. A. Cooper \& G. D. Williams), pp. 105-22. Geological Society of London, Special Publication no. 44.

ButLeR, R. W. H. \& MAZzOLI, S. 2006. Styles of continental contraction: A review and introduction. In Styles of Continental Contraction (eds S. Mazzoli \& R. W. H. Butler), pp. 1-10. Geological Society of America, Boulder, Special Paper no. 414.

Butler, R. W. H., Tavarnelli, E. \& Grasso, M. 2006. Structural inheritance in mountain belts: an AlpineApennine perspective. Journal of Structural Geology 28, 1893-908.

Carola, E., Tavani, S., Ferrer, O., Granado, P., Quintà, A., BuTILlÉ, M. \& MuÑOZ, J .A. 2013. Along-strike extrusion at the transtion between thin- and thick-skinned domains in the Pyrenean Orogen (northern Spain). In Thick-skinned Dominated Orogens: From Initial Inversion to Full Accretion (eds M. Nemčok, A. Mora \& J.W. Cosgrove), pp. 119-40. Geological Society of London, Special Publication no. 377.

CARrERA, N. \& MUÑOZ, J. A. 2013. Thick-skinned tectonic style resulting from the inversion of previous structures in the southern Cordillera Oriental (NW Argentine Andes). In Thick-skinned Dominated Orogens: From Initial Inversion to Full Accretion (eds M. Nemčok, A. Mora \& J. W. Cosgrove), pp. 119-40. Geological Society of London, Special Publication no. 377.

Cartwright, J. A., Mansfield, C. \& Trudgill, B. 1996. The growth of normal faults by segment linkage. 
In: Modern Developments in Structural Interpretation, Validation and Modelling (eds P. G. Buchanan \& D. A. Nieuwland), pp. 163-77. Geological Society of London, Special Publication no. 99.

Castelluccio, A., Andreucci, B., Zattin, M., Ketchman, R. A., JANKOWSKi, L., MAZzoli, S. \& SZANIAWSKI, R. 2015. Coupling sequential restoration of balanced cross sections and low-temperature thermochronometry: the case study of the Western Carphatians. Lithosphere 7, 367-78.

Cloetingh, S. \& Burov, E. B. 1996. Thermomechanical structure of European continental lithosphere: constraints from rheological profiles and EET estimates. Geophysical Journal International 124, 695-723.

Cloetingh, S. A. P. L., Burov, E., Matenco, L., Toussaint, G., Bertotti, G., ANDRIESSEN, P. A. M., Wortel, M. J. R. \& SPAKMAN, W. 2004. Thermo-mechanical controls on the mode of continental collision in the SE Carpathians (Romania). Earth and Planetary Science Letters 218, 57-76.

COOPER, M. 2007. Structural style and hydrocarbon prospectivity in fold and thrust belts: a global view. In Deformation of the Continental Crust: The Legacy of Mike Coward (eds A. C. Ries, R. W. H. Butler \& R. H. Graham), pp. 447-72. Geological Society of London, Special Publication no. 272.

CORNFIELD, S. \& SHARP, I. R. 2000. Structural style and stratigraphic architecture of fault propagation folding in extensional settings: a sesmic example from the Smørbukk area, Halten Terrace, Mid-Norway. Journal of Basin Research 12, 329-41.

Cosgrove, J. W. \& AMEen, M. S. 2000. A comparison of the geometry, spatial organization and fracture patterns associated with forced folds and buckle folds. In: Forced Folds and Fractures (eds J. W. Cosgrove \& M. S. Ameen), pp. 7-21. Geological Society of London, Special Publication no. 169.

DANIŠİ, M., KoHÚT, M., BROSKA, I \& FrISCH, W. 2010. Thermal evolution of the Malá Fatra Mountains (Central Western Carpathians): insights from zircon and apatite fission track thermochronology. Geologica Carpathica 61, 19-27.

DAvis, D. M. \& ENGELDER, T. 1985. The role of salt in fold-and-thrust belts. Tectonophysics 119, 67-88.

DeCelles, P. \& Gilles, K. A. 1996. Foreland basin systems. Basin Research 8, 105-23.

Decker, K., Meschede, M. \& Ring, U. 1993. Fault slip analysis along the northern margin of the Eastern Alps (Molasse, Helvetic Nappes, North- and South-Penninic flysch, and the Northern Calcareous Alps). Tectonophysics 223, 291-312.

DeCKer, K. \& Peresson, H. 1996. Tertiary kinematics in the Alpine-Carpathian-Panonnian system: links between thrusting, transform faulting and crustal extension. In Oil and Gas in Alpidic Thrustbelts and Basins of Central and Eastern Europe (eds G. Wessely \& W. Liebl), pp. 69-77. Geological Society of London, EAGE Special Publication no. 5.

Dellmour, R. \& Harzhauser, M. 2012. The Iván̆ Canyon, a large Miocene canyon in the Alpine-Carpathian Foredeep. Marine and Petroleum Geology 38, 83-94.

DesegaulX, P., Kooi, H. \& Cloetingh, S. 1991. Consequences of foreland basin development on thinned continental lithosphere: application to the Aquitaine basin (SW France). Earth and Planetary Science Letters 106, 116-32.

DESTRO, N. 1995. Release fault: a variety of cross fault in liked extensional fault systems in the Sergipe-Alagoas basin, north-eastern Brazil. Journal of Structural Geo$\log y$ 17, 615-29.

DEWEY, J. 1988. Extensional collapse of orogens. Tectonics 7(6), 1123-39, doi: 10.1029/TC007i006p01123.

Embey-Isztin, A., Downes, H., James, D. E., Upton, B. G. J., Dobosi, G., Ingram, G. A., Harmon, R. S. \& SCHARBERT, H. G. 1993. The petrogenesis of Pliocene alkaline volcanic rocks from the Pannonian Basin, Eastern Central Europe. Journal of Petrology 34, 317-43.

ERdős, Z., Huismans, R. S., VAN DER BEeK, P. \& Thieulot, C. 2014. Extensional inheritance and surface processes as controlling factors of mountain belt structure. Journal of Geophysical Research 119, 9042-61, doi: 10.1002/2014JB011408.

FARZIPOUR-SAEIN, A., Nilfouroushan, F. \& Koyi, H. 2013. The effect of basement step/topography on the geometry of the Zagros fold and thrust belt (SW Iran): an analogue modeling approach. International Journal of Earth Sciences 102, 2117-35.

FODOR, L. 1995. From transpression to transtesion: Oligocene-Miocene structural evolution of the Vienna Basin and the East-Alpine-Western Carpathian junction. Tectonophysics 242, 151-82.

Fossen, H. 2000. Extensional tectonics in the Caledonides: Synorogenic or postorogenic. Tectonics 19, 213-24, doi: 10.1029/1999TC900066.

Frisch, W., KuHLEMANN, J., DunKL, I. \& BRÜGL, A. 1998. Palispastic reconstruction and topographic evolution of the Eastern Alps during the late Tertiary tectonic extrusion. Tectonophysics 297, 1-15.

García-Castellanos, D. \& Cloetingh, S. 2012. Modelling the interaction between lithospheric and surface processes in foreland basins. In Tectonics of Sedimentary Basins: Recent Advances, 1st edition (eds C. Busby \& A. Azor), pp. 152-81. Chichester: Blackwell Publishing Ltd.

García-Castellanos, D., Fernàndez, M. \& Torné, M. 1997. Numerical modelling of foreland basin formation: a program relating thrusting, flexure, sediment geometry and lithosphere rheology. Computers and Geosciences 23, 993-1003.

Genser, J., Cloetingh, S. \& Neubauer, F. 2007. Late orogenic rebound and oblique Alpine convergence: new constraints from subsidence analysis of the Austrian Molasse basin. Global and Planetary Change 58, 214 33.

Gillcrist, R., Coward, M. P. A. \& Mugnier, J. L. 1987. Structural inversion and its controls: examples from the Alpine foreland and the French Alps. Geodinamica Acta 1, 5-34.

Goofey, G. P., Craig, J., NeEdham, T. \& Scott, R. 2010. Fold-thrust belts: overlooked provinces or justifiably avoided. In: Hydrocarbons in Contractional Belts (eds G. P. Goofey, J. Craig, T. Needham \& R. Scott), pp. 1-6. Geological Society of London, Special Publication no. 348.

Grassl, H., Neubauer, F., Millahn, K. \& Weber, F. 2004. Seismic image of the deep crust at the eastern margin of the Alps (Austria): indications for crustal extension in a convergent orogen. Tectonophysics 380, 105-22.

Graveleau, F., Malavieille, J. \& Dominguez, S. 2012. Experimental modelling of orogenic wedges: a review. Tectonophysics 538-540, 1-66.

Handy, M. R., SCHMid, S. M., Bousquet, R., Kissling, E. \& BERNOULLI, D. 2010. Reconciling plate-tectonic reconstructions of Alpine Tethys with the geologicalgeophysical record of spreading and subduction in the Alps. Earth Sciences Reviews 120, 121-58. 
HANDY, M. R., UstaszewsKi, K. \& KisSLING, E. 2015. Reconstructing the Alps-Carpathians-Dinarides as a key to understanding switches in subduction polarity, slab gaps and surface motion. International Journal of Earth Sciences 104, 1-26.

Harzhauser, M., Boehme, M., Mandic, O. \& HofmanN, CH-CH. 2002. The Karpatian (Late Burdigalian) of the Korneuburg Basin: a palaeoecological and biostratigraphical synthesis. Beitraege zur Palaeontologie 27, 441-56.

HAYWARD, A. B. \& GRAHAM, R. H. 1989. Some geometrical characteristics of inversion. In Inversion Tectonics (eds M. A. Cooper \& G. D. Williams), pp. 201-19. Geological Society of London, Special Publication no. 44.

Hinsch, R., Decker, K. \& Peresson, H. 2005. 3-D seismic interpretation and structural modelling in the Vienna Basin: implications for Miocene to recent kinematics. Austrian Journal of Earth Sciences 97, $38-50$.

HOLDSWORTH, R. E. 2004. Weak faults - rotten cores. Science 303, 181-2.

Hölzel, M., Decker, K., ZÁmolyi, A., Strauss, P. \& WAGREICH, M. 2010. Lower Miocene structural evolution of the central Vienna Basin (Austria). Marine and Petroleum Geology 27, 666-81.

JACKSON, C. A. L., GAWTHORPE, R. L. \& SHARP, I. R. 2006. Style and sequence of deformation during extensional fault-propagation folding: examples from the Hammam Faraun and El-Qaa fault blocks, Suez Rift, Egypt. Journal of Structural Geology 28, 519-35.

JAEGER, G. D. \& COOK, N. G. W. 1979. Fundamentals of Rock Mechanics. London: Chapman \& Hill Ltd., 515 pp.

JAMMES, S. \& HUISMANS, R. S. 2012. Structural styles of mountain building: controls of lithospheric rheologic stratification and extensional inheritace. Journal of Geophysical Research 117, B10403, doi: 10.1029/2012JB009376.

JANOSCHEK, W. R., MALzER, O. \& ZIMMER, W. 1996. Hydrocarbons in Austria: past, present and future. In Oil and Gas in Alpidic Thrustbelts and Basins of Central and Eastern Europe (eds G. Wessely \& W. Liebl), pp. 43-63. Geological Society of London, EAGE Special Publication no. 5.

KhaliL, S. M. \& MCClay, K. R. 2002. Extensional faultrelated folding, northwestern Red Sea, Egypt. Journal of Structural Geology 24, 743-62.

KISSLING, R. 1993. Deep structure of the Alps - What do we really know? Physics of the Earth and Planetary Interiors 79, 87-112.

Kröll, A. \& Wessely, G. 2001. Geologische Karte de Molassebasis. In Geologische Themenkarten der Republik Österreich, 1:200.000. Molassezone Niederösterreich und angrenzende Gebiete, 4 Themenkarten mit Erläut. Wien: Geologische Bundesanstalt.

Kroner, U., MANSY, J. L., MAZUR, S., ALEKSANDROWSKI, P., HANN, H. P. \& HUCKRIEDE, H. 2008. Variscan tectonics. In: The Geology of Central Europe: Vol. 1 Precambrian and Paleozoic (ed. T. Mc Cann), pp. 665-712. Geological Society of London.

LACOMBE, O. \& MOUTHEREAU, F. 2002. Basement-involved shortening and deep detachment tectonics in foreland of orogens: Insigths from recent collision belts (Taiwan, Western Alps, Pyrenees). Tectonics 21(4), doi: 10.1029/2001TC901018.

Lacombe, O., Mouthereau, F. \& Angelier, J. 2003. Frontal belt curvature and oblique ramp development at an obliquely collided irregular margin: geometry and kinematics of the NW Taiwan fold-thrust belt. Tectonics 22(3), doi: 10.1029/2002TC001436.

Lankreijer, A., Bielik, M., Cloetingh, S. \& Majcin, D. 1999. Rheology predictions across the western Carpathians, Bohemian massif, and the Pannonian basin. Implications for tectonic scenarios. Tectonics 18, 1139-53.

Legrain, N., DiXon, J., STÜWE, K., VON BlanCKENBURG, F. \& KUBIK, P. 2015. Post-Miocene landscape rejuvenation at the eastern end of the Alps. Lithosphere 7, 3-13.

LENHARDT, W. A., Švankara, J., Melaichar, P., PAZDírkovÁ, J., HAVÍre, J. \& SÝKOROVÁ, Z. 2007. Seismic activity of the Alpine-Carpathian-Bohemian Massif region with regard to geological and potential field data. Geologica Carpathica 58, 397-412.

LINZER, H.-G. 1996. Kinematics of retreating subduction along the Carpathian arc, Romania. Geology 24, 16770 .

Linzer, H.-G., DeCKer, K., Peresson, H., Dell'Mour, R. \& FRISCH, W. 2002. Balancing lateral orogenic float of the Eastern Alps. Tectonophysics 354, 211-37.

Linzer, H.-G., Moser, F., Nemes, F., RATschbacher, L. \& SPERNER, B. 1997. Build-up and dismembering of a classical fold-thrust belt: from non-cylindrical staking to lateral extrusion in the eastern Northern Calcareous Alps. Tectonophysics 272, 97-124.

LINZER, H.-G., RATSCHBACHER, L. \& FRISCH, W. 1995. Transpressional collision structures in the upper crust: the fold-thrust belt of the Northern Calcareous Alps. Tectonophysics 242, 41-61.

LipPitsch, R., Kissling, E. \& ANSORGE, J. 2003. Upper mantle structure beneath the Alpine orogen from highresolution teleseismic tomography. Journal of Geophysical Research 108, 2376, doi: 10.1029/2002JB002016.

MACEDO, J. \& MARSHAK, S. 1999. Controls on the geometry of fold-thrust salients. Geological Society of America Bulletin 111, 1808-22.

Magni, V., Faccena, C., van Hunen, J. \& Funicello, F. 2013. Delamination vs. break off: the fate of continent collision. Geophysical Research Letters 40, 285-9.

MALAVIEILLE, J. 2010. Impact of erosion, sedimentation, and structural heritage on the structure and kinematics of orogenic wedges: analogue models and case studies. GSA Today 20(1), doi: 10.1130/GSATG48A.1.

MANDIC, O. 2004. Foraminiferal paleocology of a subarine swell - the Lower Badenian (Middle Miocene) of the Mailberg Formation at the Buchberg in the Eastern Alpine Foredeep: initial report. Annalen des Naturhistorischen Museums in Wien 105, 161-74.

MARSHAK, S. 2004. Salients, recesses, arcs, oroclines, and syntaxes: a review of ideas concerning the formation of map-view curves in fold-thrust belts. In Thrust tectonics and Hydrocarbon Systems (ed. K. R. McClay), pp. 13156. The American Association of Petroleum Geologists, Tulsa, Memoir no. 82.

Márton, E., Grabowski, J., PlašIEnKa, D., TúNYi, I., Krobicki, M., HAAS, J. \& PETHE, M. 2013. New paleomagnetic results from the Upper Cretaceous red marls of the Pieniny Klippen Belt, Western Carpathians: Evidence for general CCW rotation and implications for the origin of the structural arc formation. Tectonophysics 592, 1-13.

MÁRton, E., Kuhlemann, J., Frisch, W. \& DunKL, I. 2000. Miocene rotations in the Eastern Alps - palaeomagnetic results from intramontane basin sediments. Tectonophysics 323, 163-82.

MAURIN, J. C. \& NIVIERE, B. 2000. Extensional forced folding and decollement of the pre-rift series along the Rhine graben and their influence on the geometry of the syn-rift 
sequences. In Forced Folds and Fractures (eds J. W. Cosgrove \& M. S. Ameen), pp. 73-86. Geological Society of London, Special Publication no. 169.

MAZzoLI, S., JANKOWSKI, L., SZANIAWSKI, R. \& ZATTIN, M. 2010. Low-T thermochronometric evidence for postthrusting $(<11 \mathrm{Ma})$ exhumation in the Western Outer Carpathians, Poland. Comptes Rendus - Geoscience 342, $162-9$.

MCKENZIE, D. 1978. Some remarks on the development of sedimentary basins. Earth and Planetary Science Letters 40, 25-32.

Molnar, P. \& TAPPONNIER, P. 1975. Cenozoic tectonics of Asia: effects on a continental collision. Science 189, 419-26.

Mouthereau, F., Deffontaines, B., Lacombe, O. \& ANGELIER, J. 2002. Variations along the strike of the Taiwan thrust belt: basement control on structural style, wedge geometry, and kinematics. In Geology and Geophysics of an Arc-Continent Collision, Taiwan, Republic of China (eds T. B. Byrne \& C. S. Liu), pp. 35-58. Geological Society of America, Boulder, Special Paper no. 358.

Mouthereau, F., Watts, A. B., \& Burov, E. 2013. Structure of orogenic belts controlled by lithospheric age. Nature Geoscience 6, 785-9.

Mugnier, J. L., Baby, P., Colletta, B., Vinour, P., BAle, P. \& LETURMY, P. 1997. Thrust geometry controlled by erosion and sedimentation: a view from analogue models. Geology 25, 427-30.

Muñoz, J., Beamund, E., Fernández, O., Arbués, P., DinARÈs-Turell, J. \& PoBlet, J. 2013. The Ainsa Fold and Trust oblique zone of the central Pyrenees: kinematics of a curved contractional system from paleomagnetic and structural data. Tectonics 32, 1142-75, doi: 10.1002/tect.20070.

NACHTMANN, W. \& WAGNER, L. 1987. Mesozoic and early Tertiary evolution of the Alpine foreland in Upper Austria and Salzburg, Austria. Tectonophysics 137, 61-76.

NemcoK, M., Pospisil, L., LeXA, J. \& Donelick, R. A. 1998. Tertiary subduction and slab break-off model of the Carpathian-Pannonian region. Tectonophysics 295, 307-40.

Neubauer, F., Genser, J. \& HANDLER, R. 1999. The Eastern Alps: results of a two-stage collision process. Mitteilungen der Österreichischen Geologischen Gesellschaft 92 , $117-34$.

NeUbauer, F. \& HANDLER, R. 1999. Variscan orogeny in the Eastern Alps and Bohemian Massif: how do these units correlate. Mitteilungen der Österreichischen Geologischen Gesellschaft 92, 35-59.

Nilfouroushan, F. \& KOYI, H. A. 2007. Displacement fields and finite strains in a sandbox model simulating a fold-thrust-belt. Geophysical Journal International 169, 1341-55.

Nilfouroushan, F., Pysklywec, R., Cruden, A. \& Koyi, H. 2013. Thermal-mechanical modeling of salt-based mountain belts with pre-existing basement faults: application to the Zagros fold and thrust belt, southwest Iran. Tectonics 32, 1212-26.

PEACOCK, D. C. P. \& SANDERSON, D. J. 1991. Displacements, segment linkage and relay ramps in normal fault zones. Journal of Structural Geology 13, 721-33.

PERESSON, H. \& DECKER, K. 1997. Far-field effects of Late Miocene subduction in the Eastern Carpathians: E-W compression and inversion of structures in the AlpineCarpathian-Pannonian region. Tectonics 16, 38-56.

Perrin, C., Clemenzi, L., Malavieille, J., Molli, G., TABOADA, A. \& DOMINGUEZ, S. 2013. Impact of erosion and décollements on large-scale faulting and folding in orogenic wedges: analogue models and case studies. Journal of the Geological Society 170, 893-904.

Piller, W. E., HARZHAUSER, M. \& MANDIC, O. 2007. Miocene Central Paratethys stratigraphy - current status and future directions. Stratigraphy 4, 151-68.

PlatT, J. P. 1986. Dynamics of orogenic wedges and the uplift of high-pressure metamorphic rocks. Geological Society of America Bulletin 96, 1037-53.

QORBAnI, E., BIANCHI, I. \& BoKelmanN, G. 2014. Slab detachment under the Eastern Alps seen by seismic anisotropy. Earth and Planetary Science Letters 409, 96-108.

RAMSAY, J. G. 1967. Folding and Fracturing of Rocks. New York: McGraw-Hill, $568 \mathrm{pp}$.

RATSCHBACHER, L., FrisCH, W., LINZER, H. G. \& MERLE, O. 1991. Lateral extrusion in the Eastern Alps, 2. Structural analysis. Tectonics 10, 257-71.

REBAÏ, S., PHILIP, H. \& TABOADA, A. 1992. Modern tectonic stress field in the Mediterranean region: evidence for variation in stress directions at different scales. Geophysical Journal International 110, 106-40.

REINECKER, J. \& LENHARDT, W. A. 1999. Present-day stress field and deformation in eastern Austria. International Journal of Earth Sciences 88, 532-50.

RoEDER, D. 2010. Fold-thrust belts at Peak Oil. In Hydrocarbons in Contractional Belts (eds G. P. Goofey, J. Craig, T. Needham \& R. Scott), pp. 7-31. Geological Society of London, Special Publication no. 348.

ROYDEN, L. H. 1985. The Vienna basin: a thin-skinned pullapart basin. In Strike Slip Deformation, Basin Formation and Sedimentation (eds. K. Biddle \& N. Kristie-Blick), pp. 319-38. Society of Economic Paleontologists and Mineralogists, Special Publication no. 37.

Ruh, J. B., Kaus, B. J. P. \& Burg, J.-P. 2012. Numerical investigation of deformation mechanics in fold-and-thrust belts: influence of rheology of sigle and multiple décollements. Tectonics 31 TC3005, doi: 10.1029/2011TC003047.

SACHSEnhofer, R. F., Bechtel, A., KuffNer, T., RAIner, Gratzer, R., SAUER, R. \& SPERL, H. 2006. Depositional environment and source potential of Jurassic coal-bearing sediments (Gresten Formation, Höflein gas/condensate field, Austria). Petroleum Geoscience 12, 99-114.

Sachsenhofer, R. F., Kogler, A., Polesny, H., Strauss, P. \& WAGREICH, M. 2000. The Neogene Fohnsdorf Basin: Basin formation and basin inversion during the lateral extrusion in the Eastern Alps (Austria). International Journal of Earth Sciences 89: 415-30.

SAlas, R., Guimerà, J., Mas, R., Martín-Closas, C., MeléndeZ, A. \& Alonso, A. 2001. Evolution of the Mesozoic Central Iberian System and its Cainozoic inversion (Iberian Chain). In Peri-Tethys Memoir 6: Peri-Tethyan Rift/Wrench Basins and Passive Margins (eds P. A. Ziegler, W. Cavazza, A. H. F. Robertson \& S. Crasquin-Soleau), pp. 145-85. Muséum National d'Histoire Naturelle, Paris, Memoir no. 186.

SAuer, R., Seifert, P. \& Wessely, G. 1992. Guidebook to excursions in the Vienna Basin and the adjacent AlpineCarpathian thrust belt in Austria. Mitteilungen der Österreichischen Geologischen Gesellschaft 85, 1-264.

SCHLUNEGGER, F. \& Kissling, E. 2015. Slab rollback orogeny in the Alps and evolution of the Swiss Molasse Basin. Nature Communications 6, 1-10, doi: 10.1038/ncomms9605.

Schmid, S. M., FÜGEnshchuH, B., KISSLING, E. \& SCHUSTER, R. 2004. Tectonic map and overall architec- 
ture of the Alpine orogen. Eclogae Geologicae Helvetiae 97, 93-117.

SCHRÖDER, B. 1987. Inversion tectonics along the western margin of the Bohemian Massif. Tectonophysics 137, 93-100.

Seghedi, I., Downes, H., Vaselli, O., Szakács, A., BAlOGH, K. \& PÉCSKAY, Z. 2004. Post-collisional Tertiary-Quaternary mafic alkalic magmatism in the Carpathian-Pannonian region: a review. Tectonophysics 393, 43-62.

SIBSON, R. H. 1983. Continental fault structure and the shallow earthquake source. Journal of the Geological Socity of London 140, 741-67.

SIBSON, R. H. 1985. A note of fault reactivation. Journal of Structural Geology 7, 751-4.

SiBSON, R. H. 1990. Rupture nucleation on unfavorably oriented faults. Bulletin of the Seismological Society of America 80, 1580-604.

STEARNS, D. W. 1978. Faulting and forced folding in the Rocky Mountain foreland. In: Laramide Folding Associated with Basement Block Faulting in the Western United States (V. Matthews III, ed.), pp. 1-38. Geological Society of America, Memoir no. 151.

Strauss, P., Harzhauser, M., Hinsch, R. \& Wagreich, M. 2006. Sequence stratigraphy in a classic pull-apart basin (Neogene, Vienna Basin). A 3D seismic based integrated approach. Geologica Carpathica 57, 185-97.

StraUSs, P., WAGREICH, M., DECKER, K. \& SACHSENHOFER, R. F. 2001. Tectonics and sedimentation in the Fohnsdorf-Seckau Basin (Miocene, Austria): from a pull-apart basin to a half-graben. International Journal of Earth Sciences 90, 549-59.

SZANIAWSKI, R., MAZzOLI, S., JANKOWSKI, L. \& ZATTIN, M. 2013. No large-magnitude tectonic rotations of the Subsilesian Unit of the Outer Western Carpathians: evidence from primary magnetization recorded in hematitebearing Węglówka Marls. Journal of Geodynamics 71, $14-24$.

TARI, G. 2005. The divergent continental margins of the Jurassic proto-Pannonian Basin: implications for the petroleum systems of the Vienna Basin and Moesian Platform. In 25th Annual Bob. F. Perkins Research Conference: Petroleum Systems of Divergent Continental Margin Basins. Society of the Sedimentary Geology, Gulf Coast Section, 955-86.

Tavani, S., Arbués, P., Snidero, M., Carrera, N. \& MUÑOZ, J. A. 2011. Open Plot Project: an open-source toolkit for 3-D structural data analysis. Solid Earth 2, 53-63.

TAVANI, S. \& GRANADO, P. 2015. Along-strike evolution of folding, stretching and breaching of supra-salt strata in the Plataforma Burgalesa extensional forced fold system (northern Spain). Basin Research 27, 573-85.

Thomas, D. W. \& CowARD, M. P. 1995. Late JurassicEarly Cretaceous inversion of the northern East Shetland Basin, northern North Sea. In Basin Inversion (eds J. G. Buchanan \& P. G. Buchanan), pp. 275-306. Geological Society of London, Special Publication no. 88.

ThÖNY, W., ORTNER, H. \& SchOlger, R. 2006. Paleomagnetic evidence for large en-bloc rotations in the Eastern Alps during Neogene orogeny. Tectonophysics 414, 169-89.

TRANSALP Working Group. 2002. First deep seismic reflection images of the Eastern Alps reveal giant crustal wedges and transcrustal ramps. Geophysical Research Letters 29, doi: 10.1029/2001GL014911.

TurcotTe, D. L. \& SchuberT, G. 1982. Geodynamics. New York: Wiley.
TuRneR, J. P. \& Williams, G. A. 2004. Sedimentary basin inversion and intra-plate shortening. Earth-Science Reviews 65, 277-304.

Twiss, R. J. \& Moores, E. M. 1992. Structural Geology. San Francisco: Freeman.

Ustaszewski, K., Schmid, S., FÜGENSCHUH, B., TISCHLER, M., Kissling, E. \& SpaKman, W. 2008. A map-view restoration of the Alpine-Carpathian-Dinaridic system for the Early Miocene. Swiss Journal of Geosciences 101, 273-94.

Vernant, Ph., Nilforoushan, F., Hatzfeld, D., ABbasi, M. R., VignY, C., MASSON, F., NANKALI, H., MARTINOD, J., Ashtiani, A., Bayer, R., TAVAKoli, F. \& ChÉry, J. 2004. Present-day crustal deformation and plate kinematics in the Middle East constrained by GPS measurements in Iran and northern Oman. Geophysical Journal International 157, 381-98.

VonBlanckenburG, F. \& DAVIES, J. H. 1995. Slab breakoff: A model for syncollisional magmatism and tectonics in the Alps. Tectonics 14, 120-31.

WAGNER, L. R. 1996. Stratigraphy and hydrocarbons in the Upper Austrian Molasse Foredeep (active margin). In Oil and Gas in Alpidic Thrustbelts and Basins of Central and Eastern Europe (eds. G. Wessely \& W. Liebl), pp. 217-35. Geological Society of London, EAGE Special Publication no. 5.

WAGNER, L. R. 1998. Tectono-stratigraphy in the Molasse Foredeep of Salzburg, Upper and Lower Austria. In Cenozoic Foreland Basins of Western Europe (eds A. Mascle, C. Puigdefäbregas, H. P. Luterbacher \& M. Fernàndez), pp. 339-69. Geological Society of London, Special Publication no. 134.

WATTS, A. B. \& BuROV, E. B. 2003. Lithospheric strength and its relationships to the elastic and seismogenic layer thickness. Earth and Planetary Science Letters 213, 113-31.

Wessely, G. 1987. Mesozoic and Tertiary evolution of the Alpine-Carpathian foreland in eastern Austria. Tectonophysics 137, 45-9.

WESSELY, G. 1988. Structure and development of the Vienna Basin in Austria. In The Pannonian Basin: a Study of Basin Evolution (eds L. H. Royden \& F. Horvarth), pp. 333-46. America Association of Petroleum Geologists, Memoir no. 45.

Wessely, G. 2006. Geologie der Österreichischen Bundesländer. Geologische Bundesanstalt, Wien, 416 pp.

White, N. J., JACKson, J. A. \& McKenZie, D. P. 1986 The relationship between the geometry of normal faults and that of the sedimentary layers in their hanging walls. Journal of Structural Geology 8, 897909.

Willemse, E. J. M., Pollard, D. D. \& Aydin, A. 1996. Three-dimensional analysis of slip distributions on normal fault arrays with consecuences for fault scaling. Journal of Structural Geology 18, 295-309.

Williams, G. D., Powell, C. M. \& CoOper, M. A. 1989. Geometry and kinematics of inversion tectonics. In Inversion Tectonics (eds M. A. Cooper \& G. D. Williams), pp. 3-15. Geological Society of London, Special Publication no. 44.

Withjack, M. O., Olson, J. \& Peterson, E. 1990. Experimental models of extensional forced folds. American Association of Petroleum Geologists Bulletin 74, 1038 54.

WiTHJACK, M. O. \& SCHLISCHE, R. W. 2006. Geometric and experimental models of extensional fault-bend folds. In Analogue and Numerical of Crustal-Scale Processes 
(eds S. J. H. Buiter \& G. Schreurs), pp. 285-305. Geological Society of London, Special Publication no. 253.

Wölfler, A., Kurz, W., Frizt, H. \& StüWe, K. 2011. Lateral extrusion in the Eastern Alps revisited: refining the model by thermochronological, sedimentary, and seismic data. Tectonics 30, TC4006, doi: 10.1029/2010TC002782.

XiaO, H. \& SupPe, J. 1992. Origin of rollover. American Association of Petroleum Geologists Bulletin 76, 50929.

Zattin, M., Andreucci, B., Jankowski, L., Mazzoli, S. \& SZANIAWSKI, R. 2011. Neogene exhumation in the Outer Western Carpathians. Terra Nova 23, 283-91.

Ziegler, P. A., Cloetingh, S., Guiraud, R. \& StAmpfli, G. 2001. Peri-Tethyan platforms: constraints on dynamics of rifting and basin inversion. In Peri-Tethys Memoir 6: Peri-Tethyan Rift/Wrench Basins and Passive Margins (eds P. A. Ziegler, W. Cavazza, A. H. F. Robertson
\& S. Crasquin-Soleau), pp. 9-49. Muséum National d'Histoire Naturelle, Paris, Memoir no. 186.

Ziegler, P. A., Cloetingh, S. \& VAn Wees, J. D. 1995. Dynamics of intra-plate compressional deformation: the Alpine foreland and other examples. Tectonophysics 252, 7-59.

ZIEGler, P. A., VAN WeES, J. D. \& Cloetingh, S. 1998. Mechanical controls on collision-related compressional intraplate deformation. Tectonophysics $\mathbf{3 0 0}$, 103-29.

ZIMMER, W. \& WESSELY, G. 1996. Exploration results in thrust and sub-thrust complexes in the Alps and below the Vienna Basin in Austria. In Oil and Gas in Alpidic Thrustbelts and Basins of Central and Eastern Europe (eds G. Wessely \& W. Liebl), pp. 81-107. Geological Society of London, EAGE Special Publication no. 5.

ZoBACK, M. D. 2010. Reservoir Geomechanics. Cambridge, UK: Cambridge University Press, 449 pp. 